\title{
Stock Market Reaction to Policy Interventions
}

\author{
Franco Fiordelisia ${ }^{\mathbf{a} b}$, Giuseppe Galloppo ${ }^{\mathrm{c}}$ \\ ${ }^{a}$ Middlesex Business School, U.K. \\ ${ }^{b}$ University of Rome III, Italy \\ ${ }^{b}$ University of Viterbo "La Tuscia", Italy
}

\begin{abstract}
We analyse stock price reactions to the announcements of monetary and fiscal policy actions in twelve stock exchanges worldwide between 1 June 2007 and 30 June 2012. While past papers have analysed the effect of policy interventions focusing on monetary policy actions (e.g., Ricci, 2015), our paper focuses on stock indices either capturing the whole stock market or various industries. By estimating abnormal stock reactions around the announcement date, we show that 1) stock industry indices react to policy interventions in a different manner than the broad stock index does; 2) stock returns react negatively to restriction measures for general and non-banking sector indices; and 3) stock reaction to expansionary measures was stronger at the beginning of the financial crisis.
\end{abstract}

Keywords: Fiscal stimulus, Financial crisis, Monetary policy, Asset prices, Monetary transmission

JEL code: E62; G10; G14; G18

\footnotetext{
* Franco Fiordelisi: University of Rome III, Italy and Middlesex Business School, UK, Via S. D’Amico 77, 00145 Rome, Italy; (39) 0657335 672; franco.fiordelisi@uniroma3.it; Giuseppe Galloppo: University of Viterbo “La Tuscia”, Via del Paradiso 47, 011000 Viterbo, Italy, galloppo@unitus.it
} 


\section{Introduction}

Policymakers have performed a significant number of interventions, both in terms of instruments used and number of actions run, to repair the negative effects of financial turmoil (Girardone et al., 2013; Matousek et al., 2013). Most G-20 countries have announced fiscal stimulus measures (Molyneux et al., 2013). According to Prasad et al. (2009), in 2009, the total amount of stimulus in the G-20 was $\$ 700$ billion (i.e., $1.4 \%$ of their combined GDP and 1.1\% of world GDP); more than half of the overall stimulus in 2009 was carried out by only three countries: the U.S., China and Japan. In 2010, three of the world's largest economies (the U.S., China and Germany) had planned stimulus packages raising an amount between 2\% and 3\% of their 2008 GDP; France had proposed stimulus packages amounting to only $0.7 \%$ of GDP in 2009. Similarly, monetary policy authorities worldwide developed and launched new "unconventional" forms of monetary support (Alfonso et al., 2011). Most banking systems received exceptional levels of support: for example, the total recapitalization and asset relief in European banking from 2008 to 2012 equalled nearly 1 trillion Euro (i.e., Germany 144 billion Euro, the U.K. 123 billion Euro, Spain 88 billion Euro, Ireland 65 billion Euro, Belgium 40 billion Euro, Greece 37 billion Euro, France 26 billion Euro, the Netherlands 24 billion Euro, and Italy 6 billion Euro).

Not surprisingly, an increasing number of papers have been investigating the effectiveness of policy responses to the financial crisis. Most of these papers run empirical analyses with a narrow scope, e.g., focusing on a single policy action and/or a specific market. For example, McAndrews et al. (2008) examine the effectiveness of the Federal Reserve's Term Auction Facility (TAF) in mitigating liquidity problems in the interbank funding market. Baba and Packer (2009) analyse the effect of the swap lines among central banks in reducing the dollar shortage problem. Meaning and Zhu (2011) explore the impact of recent purchases of Treasury 
securities by the Federal Reserve and the impact of gilts by the Bank of England on government bond yields. Pennathur et al. (2014) examine market reaction to nine U.S. government interventions in response to the crisis in various types of financial institutions (banks, savings and loan associations, insurance companies, and real estate investment trusts) and show that these measures generally result in an increase in risk and a reduction in value. Ricci (2015) analyses the impact of the ECB monetary policy announcements between June 2007 and June 2013 on the stock price of European banks: the paper shows that European banks were more sensitive to non-conventional measures than to interest rate decisions and that the same type of intervention may have a different impact depending on the stage of the crisis.

Only a handful of empirical papers take a broad scope and seek to assess the reaction to a large set of policy interventions in a large set of financial markets. Aït-Sahalia et al. (2012) examine the effect of a large range of policy announcements (fiscal and monetary policy, liquidity support, financial sector policy, and ad hoc bank failures) on the interbank credit and liquidity risk premia in the U.S., the Euro area, the U.K., and Japan between June 2007 and March 2009. The paper shows that policy announcements were usually associated with reductions in the LIBOR-OIS spreads; however, no one-policy action was better than another in containing the crisis. Recently, Fiordelisi and Ricci (2015) use a detailed dataset of worldwide policy interventions between June 2007 and June 2012 to analyse their effect on stock prices and CDS returns of Global Systematically Important Banks (G-SIBs). The authors show that different policy interventions from governments and central banks have produced diverse market reactions, e.g., stock market participants have generally appreciated monetary policy interventions, whichever direction (restrictive or expansionary) they have taken, in all currency areas. By contrast, failures and bail-outs have generated a strong negative reaction everywhere. 
Bredin et al. (2009) investigate the stock market response to international monetary policy changes in the UK and Germany by looking at the impact of (un)expected interest rate changes on stock returns at the industry level. The paper shows that monetary policy surprises have a significant and negative influence in both countries on stock returns on both industry- and whole market levels. Recently, Haitsma et al. (2016) run an event study to estimate the European stock market's reaction to the European Central Bank's policies during 1999-2015. Unconventional monetary policy surprises affect the EURO STOXX 50 index; value and past loser stocks also show a larger reaction to monetary policy surprises. By using the Rigobon (2003) heteroskedasticity-based approach, Kholodilin et al. (2009) also analyse the response of European stock markets to the ECB monetary policy shocks. Monetary policy tightening is found to have a heterogeneous impact on Euro area sectors on the policy announcement day.

To the best of our knowledge, none of these papers investigated stock reactions to policy announcements by distinguishing them across industries (e.g., banks vs non-banks) or countries (Europe, Asia and the US). Moreover, the previous papers mainly focused on a single company's stock return (generally, banks or financial companies), some market rates or spread (e.g., liquidity or credit-risk premia). This is surprising since the effect of policy interventions on nonfinancial companies has not been explicitly investigated given the assumption that policy changes during the crisis were only designed to help banks. This leads us to the following questions: Did policy interventions produce positive effects for all (not only financial) listed companies? Did the same policy intervention produce different effects on financial and nonfinancial companies? Did some policy actions work better than others? To answer these questions, we ran an event study estimating abnormal stock reactions (around the announcement date of a wide range of policy actions between 1 June 2007 and 30 June 2012) by focusing on 
stock indices representing the entire market ${ }^{1}$. We have four main results. First, stock industry indices react to policy interventions differently than the broad stock index (capturing the whole national stock market), which suggests the existence of portfolio diversification opportunities. Second, stock returns react negatively to restriction measures for general and non-banking sector indices. Third, stock reaction to expansionary measures is stronger during the first (and hardest) stage of the financial crisis (1 June 2007 - 14 September 2008). In final, when we consider the results connected to bank failure events, we observe negative stock returns for each index in our sample.

The contribution of our paper to the previous literature is manifold. First and foremost, our paper provides new insights on the effect that policy interventions have on non-banking companies from the 2007 financial crisis onwards. Although some previous papers analysed specific stock price effects of monetary policy actions at the industry level (e.g., Bernanke and Kuttner, 2005), no papers have assessed the effect of monetary policy during the financial crisis period at the industry level and worldwide. This is surprising since policymakers have performed a significant number of interventions (both in terms of instruments used and number of actions run) to repair the negative effects of the financial turmoil. Second, few papers (see, for example, Cassola et al. 2004, Afonso et al., 2011; Agnello et al., 2013; Jansen et al., 2008) have investigated the effects of fiscal policy on stock markets; our paper provides new insights by focusing on policy interventions over the complete financial crisis period. Specifically, our dataset enables us to consider the US subprime crisis (from 1 June 2007 to 14 September 2008), the Global Financial Crisis (GFC, from 15 September 2008 to 1 May 2010) and the sovereign

\footnotetext{
${ }^{1}$ Specifically, we focus on twelve worldwide general indices in the following financial markets: Belgium, China, France, Germany, Italy, Japan, the Netherlands, Spain, Sweden, Switzerland, the United Kingdom, and the United States. In each country, we selected economic sector data (relative to the SIC10 code) as follows: FTSE Industrials, FTSE Technology, FTSE Telecom, FTSE Utilities, FTSE Consumer \& Materials, FTSE Consumer Goods, FTSE Consumer Services, FTSE Basic Materials, FTSE Health Care, and FTSE Oil \& Gas.
} 
debt crisis (from 2 May 2011 to 30 June 2012). Third, we argue that monetary policy interventions influence not only stock prices of banks but also non-financial companies by influencing interest rates. Specifically, we argue that some industries (e.g., where high investment in tangible capital is necessary) may be more affected by policy interventions than others, so there may be differences in the response across industries.

The main research hypothesis investigated in our paper concerns the effect produced by every policy intervention considered during the financial crisis. Specifically, we posit that every intervention made during the crisis created value for investors (i.e., once policymakers announce an intervention, AR for stock prices increase), but we expect that there will be some differences across industries. The underlying idea is that the announcement of a "successful" policy intervention has the following impacts: a) a general impact on the economy of a country captured by the country's stock index reaction; and b) a specific impact on the stock returns of a specific industry, due to the specific characteristics of the industry itself that make its stock reaction different from the market reaction. As such, a policy intervention increases the net expected present value of a single industry stock return more than the mean of companies included in the market portfolio, so that it generates positive ARs. A policy intervention can increase the net expected present value of industry stocks for several reasons. First, the intervention might directly or indirectly reduce interest rates (and therefore the cash flows discount rate), which would more greatly influence those industries where investment duration is longer. Second, the intervention may reduce the probability of default of companies in the sector or risk premia demanded by investors; this would benefit sectors closely related to financial companies, which are the main receivers of policy interventions. Third, the intervention may also improve the value of future cash flows produced by the company in a given industry more than in another industry. 
We are not interested in investigating the reasons behind a stock's abnormal return; rather, we are interested in identifying which policy interventions have a positive impact on industry "specific" stock reactions.

The remaining part of this paper is organized as follows. We present our data and variables in Section 2, our empirical design in Section 3 and our main results in Section 4. In Section 5, we summarize our findings and discuss their policy implications.

\section{Data and Variables}

In this section, we present how we build the variable to measure the impact of policy interventions on non-financial companies. Our dependent variable is the Cumulative Abnormal Return (CAR), calculated in the following five event-windows: 1) a 1-day window (0;0), i.e., the day of the announcement; 2) a 2-day windows $(0 ;+1)$, i.e., from the day of the announcement to day +1 around the policy announcement; 3) a 2-day window $(-1 ; 0)$, i.e., from one day prior to the announcement day and the announcement day itself (in this case, we try to capture an anticipatory effect of the announcement itself); 4) a 3-day window (1-, +1), i.e., between one day prior to and following the announcement day; and 5) a 5-day window $(-1 ;+3)$, i.e., from one day prior to the announcement day and three days following the announcement.

First, we estimate CARs focusing on a stock index capturing the entire stock exchange (hereafter, referred to as the "market index"). As such, we selected the MSCI national stock indices $^{2}$ for the following ten worldwide primary countries: Belgium, France, Germany, Italy, Japan, the Netherlands, Spain, Switzerland, the United Kingdom, and the United States. These

2 General Indexes considered are the following: MSCI Belgium - PRICE INDEX, MSCI France - PRICE INDEX, MSCI Germany - PRICE INDEX, MSCI Italy - PRICE INDEX, MSCI Japan - PRICE INDEX, MSCI Netherlands PRICE INDEX, MSCI Spain - PRICE INDEX, MSCI Switzerland - PRICE INDEX, MSCI United Kingdom PRICE INDEX, and MSCI United States - PRICE INDEX. 
countries are representative of the following five currency areas: Swiss Franc, Japanese Yen, British Pound, US Dollar, and Euro. For joint announcements by two or more different central banks, we measure the reaction in every country involved in the intervention.

In the second step, we focus on industry indices in each country. Specifically, we selected the following economic sectors (relative to the SIC10 code): Oil \& Gas, Basic Materials, Industrials, Consumer Goods, Consumer Services, Health Care, Banks, IT, Telecom and Communication Services and Utilities. Similarly to the market indices, we use the FTSE indices to measure the stock returns in these industries for each country (hereafter referred to as the "industry index"). As such, our variable SECTOR $_{\mathrm{j}, \mathrm{t}}$ refers to the excess return on sector $j$ at calendar day $t$ for the following FTSE Stock Market sector indices. Due to space limitations, we discuss our results aggregating all non-banking industries in a single model that we label as "non-banking"3.

As shown below in Eq. 1, our independent variables are a set of dummy variables indicating policy interventions and financial crisis stages. Specifically, we classify policy interventions in six macro categories: 1) monetary policy expansionary (MPE) measures; 2) monetary policy restrictions and unchanged (MPRU) measures; 3) Financial Sector Support (FSS) actions; 4) State Aid and Fiscal Policy $(S A F P)$; 5) inactions measures (INA) related to bank failures and bailout events; and 6) Other (includes mainly administrative measures, e.g., restrictions on short selling).

Next, we collect data for various actions within each macro category. Specifically, we identify the following three micro actions in the first macro category (expansionary monetary

\footnotetext{
${ }^{3}$ All non-banking industries (Oil \& Gas, Basic Materials, Industrials, Consumer Goods, Consumer Services, Health Care, IT, Telecom and Communication Services and Utilities) are pooled in the same model by adding a dummy for each sector. Our results for each single non-banking industry are reported in the Appendix, which can be obtained upon request from the authors or downloaded from the authors' website.
} 
measures): interest rate cuts (IRC); liquidity support (LIQ), which includes the provision of liquidity both in domestic currency (i.e., more frequent auctions, longer maturities for refinancing operations or extensions of accepted collateral) and foreign currencies (through swap agreements between central banks or central banks' facilities for liquidity in a foreign currency); and monetary easing decisions $(M E)$. In the second macro category of policy actions (restrictions and unchanged monetary measures), we distinguish two interventions: 1) decisions to stop a monetary easing program (CONTR), e.g., the Bank of England stopping some part of the asset purchase program on 15 November 2010 after determining that it was no longer necessary given the improvements in financial market functioning, and restricted liquidity; and 2) decisions to increase the interest rate or to not change the target rates (IRC vs. IRIU). The Financial Sector Support (FSS) macro category includes the following interventions: 1) Financial support on liability $(F L)$, which are recovery measures for banks in the form of guarantees for old or new liabilities, enhancement of depositor protection schemes, and provision of lender of last resort facilities; 2) Financial Support on Equity (FR), which includes capital injections and nationalization (acquisition of controlling share); and lastly, 3) Financial support on assets (FA), which includes recovery measures for banks in the form of asset purchase or ring-fencing of bad assets and asset guarantees. The macro category of policy actions related to bank failures and bailout events includes 1) bank bailouts and assisted mergers (INAB); and 2) bank failures $(I N A F)$. The remaining two macro categories, i.e., State Aid and Fiscal Policy (SAFP) and Other (OTHER), are not split into any micro categories.

Consistent with Ricci (2015), we address the problem of overlapping events (i.e., press releases by the same institution and occurring on the same day) by adopting the following criteria: 1) if different announcements belong to the same event-type category, we treat them as a 
single event; 2) if there is a decision to change the target interest rate, we consider it as the main event, and thus, we drop the other events from the event study analysis; 3) if there is a decision to leave the current situation unchanged or to continue with a measure previously defined, we consider it less important than other announcements in the same press release; and 4) if the aforementioned criteria are not sufficient to extrapolate a single event from a package of interventions, we identify the main event on the basis of its prominence in the financial press, as in Aït-Sahalia et al. (2012). We also checked for an overlapping effect of macro release by dropping all events, including in the same day macro news. At the end of the selection process, our final sample (excluding announcements overlapping with other relevant events ${ }^{4}$ ) includes 610 events. We report some descriptive statistics in Table 1.

\section{INSERT TABLE 1}

Data are collected from various sources, including Bloomberg and Datastream. For the period from June 2007 to March 2009, we draw information from the database compiled by the National Bureau of Economic Research (Aït-Sahalia et al., 2010, 2012). For the period from April 2009 to the end of June 2012, we collect data from official announcements (in the form of press releases) of the European Central Bank, the Bank of Japan, the Bank of England, the Federal Reserve and the Swiss National Bank. Specifically, we distinguish between announcements from a single central bank ${ }^{5}$ and coordinated measures as announced in a single

\footnotetext{
${ }^{4}$ Once we excluded overlapping announcements, some cases of events (36 out of 610) remain that are separated from each other by less than 3 days. These may be considered overlapping for the longest window of our event study. However, we decided to keep them in the sample to avoid discretional selection.

${ }^{5}$ Among single announcements, we have a few cases in which central banks do not release a joint communication but independently adopt similar decisions on the same day. In our sample, there are only 4 cases, all regarding interest rate cuts: 8 October 2008 (CH, EUR, UK, US); 6 November 2008 (CH, EUR, UK); 4 December 2008 (EUR and UK); and 5 March 2009 (EUR and UK).
} 
joint press release (e.g., the Bank of England, the Bank of Japan, the European Central Bank, the Federal Reserve and the Swiss National Bank adopted joint measures on 13 October 2008 to improve liquidity in the short-term U.S. dollar funding market).

\section{Empirical strategy}

Our empirical design is based on three steps. First, we run an event study to estimate the CAR for each policy intervention looking both at the market and the industrial indices in each country. Second, we focus on the whole stock market by estimating the link between the market index CARs and the dummy capturing a specific policy action. Specifically, we run the following model to investigate policy intervention effects on the market index:

$R_{i}=\alpha+\sum_{j}^{n} \beta_{i} X_{i, j}^{M}+\theta W_{i}+\sum_{k}^{n} \gamma \operatorname{Stage}_{k, i}+\delta_{d}+\delta_{s}+\delta_{j \times t}+\varepsilon_{i}$

where $R$ is the CAR for the market index in the selected event windows for the $i$-th country. As such, we run five regression models, namely MOD Car0 for the $(0 ; 0)$ window, MOD Car13 for the $(-1 ;+3)$ window, MOD Car11 for the $(1-,+1)$ window, MOD Car01for the $(0-,+1)$ windows, and MOD Car10 for the $(-1-, 0)$ window. ${ }^{6} . X_{i, j}^{M}$ is a vector of dummy variable macro categories of policy interventions (i.e., expansionary measures or restrictions and unchanged measures), $W$ is a dummy variable indicating if there was a policy intervention in another currency area, and Stage $_{k, i}$ is a set of dummy variables indicating different stages of the financial crisis. The inclusion of fixed effects of the day of the week $\left(\delta_{d}\right)$ ensures that each indicator is estimated using only within-day of the week variation in the dependent variable, sector fixed effects $\left(\delta_{s}\right)$ control for the industry heterogeneity, time*country dummies $\left(\delta_{t \times j}\right)$ control for state $\times$ time level

\footnotetext{
${ }^{6}$ A detailed explanation of the event window estimation procedure is reported in the Appendix, which can be obtained from the authors upon request or downloaded from the authors' website.
} 
trends.

Next, we focus on industry indices by distinguishing between banks and non-banking companies. Our empirical approach is similar to the one used for the market indices (model 1): specifically, we run equation 1 replacing the dependent variable by the CARs of the banking industry sector indices (first) and the non-banking industry sector indices. In this case, we focus report and discuss results for the event window $(0,0)^{7}$. All variables are described in Table 2 .

\section{INSERT TABLE 2}

In the third step of our analysis, we run a set of "impact models" in which, one by one, each dummy capturing a macro category of policy interventions is replaced by a set of dummies indicating the micro actions of interventions. For example, the expansionary monetary policy dummy is replaced by the following variables: interest rate cuts dummy, monetary easing dummy, and provision of liquidity. To consider the possibility that several interventions have a different effect depending on the moment in which they are released, we also add the interactions between dummies identifying the micro type of interventions and dummies indicating several stages of the financial crisis. After splitting macro category of interventions into corresponding micro categories of interventions, we refer to this new set of specifications as an "Impact Model" in the Tables at the end of the paper showing the main results.

\section{Results}

\footnotetext{
${ }^{7}$ We run similar models by estimating CAR over the event windows $(-1,0),(0,1),(1-, 1)$, and $(-1,3)$ to check the consistency of our results: the results are available upon request from the authors.
} 
We present our results in two steps. First, we illustrate the reaction of market indices (section 4.1) and industry indices (section 4.2) to different macro types of policy actions (specifically, expansionary monetary policy, restrictive monetary policy and unchanged measures, state aid and fiscal policies, bank failures/bailouts interventions, and financial sector policies). In section 4.3, we present our results of the impact study models by distinguishing various policy actions within each macro class of interventions (e.g., we split the macro class "Expansionary Monetary Policy interventions" into 1) interest rate cut, 2) liquidity supporting, and 3) monetary easing).

\subsection{Macro category of policy interventions: the effect on market indices}

In this section, we discuss our results on the reaction of market indices to policy interventions by considering the macro category of interventions (Table 3). We find that stock market reactions display a different relationship with various macro categories of policy actions.

\section{$<$ INSERT TABLE $3>$}

We show that the estimated coefficients for Monetary Policy Expansionary measures (MPE) are positive and statistically significant on the announcement day (model 1 in Table 3), while the estimated coefficients related to CARs in other event windows are not found to be statistically significant at the $10 \%$ level or less. This suggests that MPE actions produce a positive influence on market indices over a very short time horizon, but we do not find statistically significant evidence of this effect over longer time periods. Regarding Monetary Policy Restriction or Unchanged (MPRU) measures, we observe negative and statistically significant coefficient estimates (in models 3 and 4 of Table 3), suggesting that $M P R U$ measures 
produce a negative influence on market indices the next day after the announcements but not on the same day.

Financial Sector Support (FSS) measures (i.e., all instruments used to resolve systemic banking crises) negatively influence market indices reactions in all models in Table 3 (expect model 2): as for the previous macro category of interventions, the effect seems to be limited to a very short time period (i.e., the announcement day and the following day). Interestingly, investors are able to anticipate the effect of financial sector support actions, as suggested by the negative estimated coefficient in model 5 of Table 3. Inaction measures (INA), related to bank failures and bailout events, display a negative relationship with market indices in two event windows (models 1 and 5), i.e., the announcement day and the day before. We show that investors not only react negatively to INA measures on the announcement day, but they also anticipate these measures, as suggested by the negative estimated coefficient in model 5 of Table 3. The estimated coefficient for the dummy capturing the residual category of policy interventions (OTHER) is negative and statistically significant (at the $10 \%$ level or lower) in models 1 and 4 of Table 3; this suggests that investors react to these interventions on the announcement day or the following day. State Aid and Fiscal policy $(S A F P)$ measures and the end of any interventions (END) do not display any statistical link with abnormal returns of market indices. Interestingly, we note that the relationship between global policy interventions $(W)$ and market indices reaction is statistically significant at the 5\% level or lower in all models (expect model 4).

The result for the dummy capturing the second and third stages of the Global Financial Crisis (D2 and D3) are found to be positive and statistically significant at the 5\% level or less, 
suggesting that market indices' reactions to policy interventions were greater during the second (15 Sept 2008 - 1 May 2010) and the third (2 May 2010 - 30 June 2012) stages of the crisis.

\subsection{Macro category of policy interventions: the effect on banking and non-financial indices}

In this section, we present our results on the reaction of industry indices to policy interventions by considering the macro category of interventions: specifically, we use stock indices for the banking industry (first) and non-banking industry (then) as dependent variables.

Focusing on banking indices, our results (Table 4) are strongly consistent with previous findings for the market indices (reported in Table 3). Coefficient estimates of expansionary monetary measures in all models in Table 4 (except model 5) are positive and statistically significant at the $5 \%$ level or less, suggesting that, on average, banking indices have a positive reaction to expansionary monetary measures.

\section{< INSERT TABLE 4 >}

The estimated coefficients for Monetary Policy Restriction measures $(M P R)$ and financial sector policy measures (FSS) are positive and statistically significant at the $5 \%$ level or less in models 2, 3 and 4. The coefficient estimates for Restrictions and Unchanged measures $(M P R U)$ exhibit a positive link when stock reaction is measured over three short event windows (i.e., [$1,3],[-1,1]$ and $[0,1])$. Looking at the magnitude of the coefficient estimates, the relationships between MPRU and CARs is stronger for banking indices than for market indices. This can perhaps be due to the fact that the increasing of interest rates implies higher interest margins for banks, and thereby, this produces positive CARs for the banking industry. The coefficient 
estimates for other interventions (OTHER) and the State Aid and Fiscal Policy $(S A F P)$ are not statistically significant at the $10 \%$ level in all event windows. Coefficient estimates for world level interventions $(W)$ show a negative relationship that is statistically significant at the $5 \%$ level between CAR when stock market reaction is measured in the event windows $(-1 ; 3)$ and $(0 ; 1)$.

We are also interested in comparing the response of the general market and banking sector in order to highlight some substantial differences. Although expansionary monetary measures produce a positive reaction both for market and banking indices, we show that banking indices are also influenced by financial sector policy interventions. Second, restrictive monetary measures are found to exhibit a positive link with stock indices in banking but a negative link in the case of market indices. This result is consistent with Ricci (2015) and the European Central Bank (2010, page 62) consideration on monetary policy effectiveness and credit channel transmission, which stresses that "the standard monetary policy measures, i.e., changes in the key interest rates, could prove insufficient in ensuring the effective transmission of monetary stance to banks and, subsequently, the real economy".

\section{$<$ INSERT TABLE $5>$}

In Table 5, we report our results related to the stock reaction of non-banking indices to policy interventions. Consistently with Bernanke et al. (2005), Ehrmann et al. (2004), and Basistha et al. (2008), we find considerable industry heterogeneity in the responses to policy interventions $^{8}$ : specifically, there is a predominance of negative signs for coefficient estimates of policy interventions in most of the sector investigated. The estimated coefficients for Monetary

\footnotetext{
${ }^{8}$ Our results for each single non-banking industry are reported in the Appendix, which can be obtained upon request from the authors or downloaded from the authors' website.
} 
Policy Expansion Measures are negative and statistically significant (at the 5\% level or less) in all event windows considered (except the longest one, i.e., [1,3]). Monetary Policy restriction measures show a negative link with CARs in all cases, except the window of the day before the announcement. The coefficient estimates for the global financial crisis period dummy (D2) are positive and statistically significant at the $1 \%$ level in all models, while we show a positive reaction for the dummy (D3), corresponding to the sovereign debt crisis period in models 4 and 5 .

Overall, our results show heterogeneity of the response to monetary shocks across all sectors of the economy. To sum up, our results (reported in Tables 3, 4 and 5) show that different types of interventions are associated with different market reactions. In the case of bank indices, the results underscore how banks are interested in any measure that regulators adopt in critical situations, since these interventions are viewed as safeguards for the general economy. In contrast, in the case of market indices (and also non-banking sector indices), stocks tend to react with a stock price reduction when restrictive measures are adopted.

\subsection{A follow-up: the effect of the micro category of policy interventions}

In this section, we present our results on the reaction of market, banking and non-banking industry indices to specific policy interventions obtained by splitting each macro category of interventions (analysed in sections 4.1 and 4.2) in specific actions. Consistently with our research design, we rearrange equation (1) as follows:

$R_{i}=\alpha+\sum_{j}^{n} \beta_{i} X_{i, j}^{M a}+\sum_{j}^{n} \beta_{i} Y_{i, j}^{m i}+\theta W_{i}+\sum_{k}^{n} \gamma$ Stage $_{k, i}+\delta_{d}+\delta_{j \times t}+\varepsilon_{i}$

where $R$ is the CAR for the market index in the selected event windows for the $i$-th country. As such, we run five regression models, namely MOD Car0 for the $(0 ; 0)$ window, MOD Car13 for 
the $(-1 ;+3)$ window, MOD Car11 for the $(1-,+1)$ window, MOD Car01for the $(0-,+1)$ window, and MOD Car10 for the $(-1-, 0)$ window. $X_{i, j}^{M a}$ is a vector of dummy variable macro categories of policy interventions (i.e., expansionary measures or restriction and unchanged measures), where $Y_{i, j}^{m i}$ is a vector of dummy variables, indicating the existence (or not) of several micro categories of policy interventions in each area, $W$ is a dummy variable indicating whether there was a policy intervention in another currency area, and $S \operatorname{tag} e_{k, i}$ is a set of dummy variables indicating different stages of the financial crisis, $\delta_{d}$ controls for the day of the week, and time*country dummies $\left(\delta_{t \times j}\right)$ control for state $\times$ time level trends. In non-banking industry models, we also include industry dummies $\left(\delta_{s}\right)$.

First, we focus on the macro category "expansionary monetary measures” by identifying the following specific actions: interest rate cuts $(I R C)$, liquidity provision $(L I Q)$, and monetary easing intervention $(M E)$. As shown in the table 6, coefficient estimates for $L I Q$ and $M E$ are positive and statistically significant at the 5\% confidence level or less for market indices, but only $L I Q$ is effective in the banking industry. Regarding the $I R C$, it is usually expected to have a positive effect on the stock market (e.g., by reducing the discount rate of future cash flows) in non-crisis periods: our results suggest that, in times of crisis, the $I R C$ generates a negative and slight statistically significant influence on market indices, while we find a negative relationship for non-financial indices and a positive relationship with banking indices. Our results suggest that during bad times, investors believe that the IRC is an effective tool for helping the banking industry, while they find that IRC interventions are not effective for the non-banking industry and, in general, for the entire stock market.

Looking at the variables obtained by the interaction of each expansionary monetary policy action (i.e., IRC, $L I Q$ and $M E$ ) and the dummies accounting for the crisis stage (D2 and 
$D 3$ ), we find that most of the coefficient estimates are negative. There are only two cases where the coefficient is positive: $L I Q^{*} D 3$ for market and non-financial indices. The negative coefficient estimates for $D 2$ and $D 3$ suggests a strong reaction during the first stage of GFC (1 June 2007 14 September 2008). This is also in line with the results of Basistha et al. (2008). The sign change for $L I Q^{*} D 2$ for the bank industry is quite interesting and underscores that Liquidity Support measures are effective for the banking system, particularly during the global financial crisis period (15 September 2008 - 1 May 2010). It is worth noting, here and in all banking sector estimates, the positive coefficient of Country Dummy related to Belgium accounting for the Dexia Bailout event ${ }^{9}$.

\section{$<$ INSERT TABLE $6>$}

Second, we focus on the macro category "restriction and unchanged monetary measures" by identifying the following specific actions: CONTR indicates the liquidity drain and end/reductions of monetary easing programs; IRIU indicates an interest rate increase or unchanged. As suggested by Bernanke et al (2005), there are three broad reasons why a fund rate increase may lead to a decline in stock prices. First, it may be associated with a decrease in expected future dividends, making the cost of borrowing for a firm higher. Second, a rise in the future expected real interest rates used to discount those dividends makes the overall discounted dividend sum lower. In addition, a rise in interest rates makes the stock market a less attractive place for the allocation of savings, also reducing the equity premium, which is the excess return that an individual stock or the overall stock market provides over a risk-free. Estimated

\footnotetext{
${ }^{9}$ Results for each single non-banking industry are reported in the Appendix, which can be obtained upon request from the authors or downloaded from the authors' website.
} 
coefficients for the IRIU are negative for market indices and non-financial indices (consistent with Gregoriou et al., 2009), while they are positive for banking indices. In the case of banks, the positive link between stock returns and the IRIU can be explained since increasing interest rates imply higher interest margins for banks. It is worth noting here and in the Fiscal Policy action model (in the next paragraph), the negative contribution of the Dummy (D2) accounting for the Global Financial crisis, to confirm that bad times occurred for the banking sector at that time.

\section{< INSERT TABLE $7>$}

Third, we focus on the macro category "fiscal policy actions", which includes stimulus packages as well as financial support to countries. As shown in Table 8, CARs react positively at the announcement day in the interaction model for market indices and non-financial indices, while the response to stimulus packages is not statistically significant in the banking sector. A positive government expenditure shock usually causes a decline in the stock market (e.g., Ardagna, 2009). Although various previous papers do not find a statistically significant effect from fiscal policy interventions (e.g., Arin et al., 2009, Agnello et al., 2013), here we believe that the difference between expected and estimated coefficients in terms of sign is to be associated with a very short-term view in trying to capture market reaction.

\section{$<$ INSERT TABLE 8 >}

In Table 9, we present the results connected to "bailout and bank failure events", i.e., $I N A B$ is related to bank bailouts and assisted mergers, and INAF is related to bank failures. 
Coefficient estimates display a negative link between both INAF and INAB for stock return for both market and non-financial indices. In the case of the banking industry, INAB displays a positive link to stock returns, while INAF shows a negative link. Our results are consistent with Veronesi and Zingales (2010), who observe that a banking bailout may have three effects on a firm value - two negative and one positive - so that the net effect depends on the relative strength of each individual effect. The positive side consists of positive investor reaction due to the reduction in the probability of bankruptcy connected with a policy action involving the support of the banking firm. Negative aspects consist of a negative signal about the true value of a firm's assets - suspected of potential bailout - that can lead to a negative investor reaction.

\section{$<$ INSERT TABLE $9>$}

Finally, we focus on "Financial Sector Policies", i.e., instruments used to resolve systemic banking crises: specifically, in this group, we have recovery measures for banks in the form of asset purchase or ring-fencing of bad assets and asset guarantees $(F A)$, recovery measures for banks in the form of guarantees for old or new liabilities, enhancement of depositor protection schemes, the provision of lender of last resort facilities $(F L)$ and capital injections and nationalization $(F R)$. Looking at the significance level and sign of regression coefficients in Table 10, the response of market indices and non-banking sectors is very similar. First, we observe a positive reaction of market and non-financial indices according to recovery measures

for banks in the form of asset purchase or ring-fencing of bad assets and asset guarantees. This measure $(F A)$ also seems to be the strongest policy action among the three categories $(F A, F L$, and $F R$ ) investigated. Second, we observe a negative reaction, related to the bank recovery 
measures group. We also observe a negative reaction, stronger than the previous one in terms of estimated parameter magnitude, for policies related to capital injections and nationalization. This last result reminds us, in some ways, of what happened for UK Asset Resolution Ltd., which caused some British banks to be fully nationalized and a tremendous rise in Central Government Debt for repayments, interest, fees and taxes. Investors can interpret this policy action as an expansionary fiscal policy, serving as a signal of a deterioration of public finances to markets (Ardagna, 2009) or a lack of fiscal discipline (Hallett et al., 2008). Fears for future tax increases to cover deficit balance may induce the private sector to dramatically decrease its consumption level in favour of savings in liquid assets, penalizing stock markets. As for bank indices, our results reveal slightly significant reactions in the form of asset purchase or ring-fencing of bad assets and asset guarantees.

\section{< INSERT TABLE $10>$}

Finally, we run a test to disentangle the anticipated and surprise effects in monetary policy actions based on interest rate decisions following the approach proposed by Bernanke and Kuttner $\left(2005^{10}\right)$. Specifically, we use the change in the futures contract's price relative to the day prior to the policy intervention as a proxy of the surprise element of any change in the interest rate target. The unexpected (or "surprise") target rate change is estimated by the change in the rate implied by the current-month futures contract, scaled up by a factor related to the number of days in the month affected by the change. As such, we estimate the expected component of the rate change as the actual change minus the surprise change.

\footnotetext{
${ }^{10} \mathrm{We}$ would like to thank one of the anonymous referees for suggesting us this additional test.
} 


\section{< INSERT TABLE 11 >}

Once we disentangled the actual change in the anticipated and surprise effects, we regress these two variables (as an independent variable) on the CAR in $(0 ; 0)$ around the announcement of monetary policy actions based on interest rate decisions (as a dependent variable). Consistently with our previous regressions, we measure the CAR focusing on three indices: market, banking and non-banking indices. As shown in Table 11, we find negative and statistically significant coefficients both for the anticipated and unanticipated effects in the case of market and non-banking indices; this suggests that higher anticipated and surprise components are related to lower CARs. These results are consistent with Bernanke and Kuttner (2005). Interestingly, we do not find statistically significant results (at the $10 \%$ level or less) in the case of banking indices.

\section{Conclusions}

This paper provides new evidence of monetary and fiscal policy actions in international markets during the recent financial crisis. Policymakers worldwide have opted for intense policy actions aimed at stabilizing and revitalizing their local stock markets. Our paper has analysed the impact of (both monetary and fiscal) policy action announcements on stock price indices in the most important financial markets worldwide (such as the US, Japan, European countries and China).

First, we assess the reaction of the market index to different types of policy actions, primarily Monetary and Fiscal Interventions. Second, we move our focus from the banking onto non-banking sectors by observing the reaction of stock indices representing these sectors. In these first two steps, we considered various macro classes of policy interventions (e.g., 
Expansionary measures, Restriction \& unchanged measures, State Aid and Fiscal Policies, Bank Failures/Bailouts interventions and Financial Sector Policies) and estimate the abnormal reaction of market, banking and non-financial indices. Third, we focus on a specific event window (i.e., the day of the press release) and we run a set of "impact models" in which, one by one, the dummies indicating a macro category of interventions are substituted by a set of dummies indicating the relative micro categories of interventions. For example, the "expansionary monetary measures" macro category is sub-divided into the following three actions: interest rate cuts, liquidity support, and monetary easing decisions.

Our most remarkable findings are as follows: 1) stock industry indices react to policy interventions in a different manner to the broad stock index (capturing the whole national stock market) suggesting the existence of portfolio diversification opportunities; 2) stock returns react negatively to restriction measures for general and non-banking sector indices; 3) stock reaction to expansionary measures is stronger during the first (and hardest) stage of the financial crisis (1 June 2007 -14 September 2008); and 4) when we consider the results connected to bank failure events, we observe negative stock returns for each index in our sample.

Our results are particularly interesting for policymakers since we provide evidence of the effect of a wide set of policy actions (some of them very new and not explored yet, such as monetary easing and liquidity support) focusing not only on financial companies but also on the whole stock market and non-banking sectors. Our paper also provides important insights to investor portfolio managers, since we show that changes in policy interventions have different implications in various industries, which is critical for investment and risk management decisions (Ioannidis et al., 2008). 


\section{References}

Agnello, L., Sousa, R., 2013. Fiscal policy and asset prices. Bulletin of Economic Research 65, $154-177$.

Aït-Sahalia, Y., Andritzky, J., Jobst, A., Nowak, S. and Tamirisa N., 2010. Market response to policy initiatives during the global financial crisis. National Bureau of Economic Research. Working paper 15809.

Aït-Sahalia, Y., Andritzky, J., Jobst, A., Nowak, S. and Tamirisa N., 2012. Market response to policy initiatives during the global financial crisis. Journal of International Economics 87, 162177.

Alfonso, A., Sousa, R.M., 2011. What are the effects of fiscal policy on asset markets?. Economic Modelling 28, 1871-1890.

Ardagna, S., 2009. Financial markets behavior around episodes of large changes in the fiscal Stance. European Economic Review 53, 37-55.

Arin, K. P., Mamun, A. and Purushothman, N., 2009. The effects of tax policy on financial markets: G3 evidence. Review of Financial Economics 18, 33-46.

Baba, N., Packer, F., 2009. From turmoil to crisis: dislocations in the FX swap market before and after the failure of Lehman Brothers. Bank for International Settlements. Working Paper No 285. Basistha, Arabinda, \& Kurov, Alexander, 2008. Macroeconomic cycles and the stock market's reaction to monetary policy. Journal of Banking and Finance 32, 2606-2616.

Bernanke, B.S., Kuttner, K.N., 2005. What explains the stock market's reaction to Federal Reserve policy?. The Journal of Finance 60, 1221-1257.

Boehmer, E., Musumeci, J. and Poulsen A. 1991. Event-study methodology under conditions of event induced variance. Journal of Financial Economics 30, 253-272. 
Bredin, D. , Hyde, S. , Nitzsche, D. , O'Reilly, G. , 2009. European monetary policy surprises: the aggregate and sectoral stock market response. Int. J. Finance Econ. 14 (2), 156-171 .

Cassola, N., Morana, C., 2004. Monetary policy and the stock market in the euro area. Journal of Policy Modeling 26, 387-399.

Chatziantoniou, I., Duffy, D., Filis, G., 2013. Stock market response to monetary and fiscal policy shocks: Multi country evidence. Economic Modelling 30, 754-769.

Ehrmann, M., Fratzscher, M., 2004. Taking stock: monetary policy transmission to equity markets. European Central Bank, Working Paper 354.

European Central Bank . 2010. The ECB's response to the financial crisis. Monthly Bulletin, 5974.

Girardone, C., J.O.S. Wilson and P. Hamill, 2013. Contemporary Issues in Financial Markets and Institutions. Editorial, The European Journal of Finance 19, 811-814.

Gregoriou, Andros, Kontonikas, Alexandros, MacDonald, Ronald, \& Montagnoli, Alberto, 2009. Monetary policy shocks and stock returns: Evidence from the British market. Financial Markets and Portfolio Management, 23, 401-410.

Haitsma, R., Unalmis, D., de Haan, J., 2016. The impact of the ECB's conventional and unconventional monetary policies on stock markets. Journal of Macroeconomics, 48, 101-116.

Hallett, A. H. and Lewis, J., 2008. European fiscal discipline before and after EMU: crash diet or permanent weight loss?. Macroeconomic Dynamics 12, 404-24.

Harrington, S. E. and Shrider, D. G., 2007. All events induce variance: Analyzing abnormal returns when effects vary across firms. Journal of Financial and Quantitative Analysis 42, 229256. 
Ioannidis, C., Kontonikas, A., 2008. The impact of monetary policy on stock prices. Journal of Policy Modeling 30, 33-53.

Jansen, D.W., Tsai, C., 2010. Monetary policy and stock returns: Financing constraints and asymmetries in bull and bear markets. Journal of Empirical Finance 17, 981-990.

Kholodilin, K. , Montagnoli, A. , Napolitano, O. , Siliverstovs, B. , 2009. Assessing the impact of the ECB's monetary policy on the stock markets: a sectoral view. Econ. Lett. 105 (3), 211213.

Kolari, J.W. and Pynnönen, S. 2010. Event study testing with cross-sectional correlation of abnormal returns. Review of Financial Papers 23, 3996-4025.

MacKinlay, A.C., 1997. Event papers in economics and finance. Journal of Economic Literature $35,13-39$.

McAndrews, J., Sarkar, A., Wang, Z., 2008. The effect of the Term Auction Facilityon the London Inter-Bank offered rate. Federal Reserve Bank of New York Staff Report 335.

Matousek, Roman, Akinci, D.A., Radic, N., Stewart, C., 2013. Monetary policy and the banking sector in Turkey. Journal of International Financial Markets, Institutions and Money 27, 269-285. Meaning, J, and Feng Z. 2011.The impact of recent central bank asset purchase programmes. BIS Quarterly Review, December.

Mentz, M. and Schiereck, D. 2008. Cross-border mergers and the cross-border effect: The case of the automotive supply industry. Review of Managerial Science 2,199-218.

Mikkelson, W.H. and Partch, M.M., 1988. Withdrawn security offerings. Journal of Financial and Quantitative Analysis 23, 119-133.

Molyneux P., M. Shahid Ebrahim and JOS Wilson, 2013. Financial sector performance and risk: An introduction. Journal of Economic Behaviour and Organization 85, 118- 122. 
Pennathur, A., Smith, D., \& Subrahmanyam, V., 2014. The stock market impact of government interventions on financial services industry groups: Evidence from the 2007-2009 crisis. Journal of Economics and Business 71, 22-44.

Prasad, E., Sorkin, I., 2009. Assessing the G-20 economic stimulus plans: A deeper look. Electronic copy at: http://papers.ssrn.com/sol3/papers.cfm?abstract_id=1611229.

Ricci, O., 2015. The impact of monetary policy announcements on the stock price of large European banks during the financial crisis. Journal of Banking \& Finance 52, 245-255.

Rigobon, R. 2003. Identification through heteroskedasticity. The Review of Economics and Statistics 85 (4), 777-792.

Veronesi, P., Zingales, L., 2010. Paulson's gift. Journal of Financial Economics 97,339-368. 
Table 1: Policy announcements between June 2007 and June 2012

This table reports the number of policy interventions collected between June 2007 and June 2012 by the macro categories of actions (Panel A) and the micro categories of actions (Panel B).

Panel A - Number of policy actions by macro type of intervention

\begin{tabular}{|c|c|c|c|c|c|c|c|}
\hline & $\begin{array}{c}\text { Financial Sector } \\
\text { Policies }\end{array}$ & $\begin{array}{c}\text { Policy Inaction and Bank } \\
\text { Failures/Bailouts }\end{array}$ & $\begin{array}{c}\text { Monetary } \\
\text { Policy }\end{array}$ & $\begin{array}{c}\text { Fiscal Policy \& } \\
\text { State Aid }\end{array}$ & $\begin{array}{c}\text { Other } \\
\text { Measures }\end{array}$ & $\begin{array}{c}\text { End of recovery or austerity } \\
\text { measures }\end{array}$ & Total \\
\hline 2007 & 5 & 1 & 33 & 0 & 14 & 0 & 53 \\
\hline 2008 & 19 & 7 & 67 & 9 & 36 & 0 & 138 \\
\hline 2009 & 34 & 5 & 89 & 10 & 44 & 12 & 194 \\
\hline 2010 & 14 & 5 & 54 & 3 & 27 & 3 & 106 \\
\hline 2011 & 5 & 1 & 59 & 5 & 10 & 0 & 80 \\
\hline 2012 & 4 & 1 & 28 & 2 & 4 & 0 & 39 \\
\hline Total & 81 & 20 & 330 & 29 & 135 & 15 & 610 \\
\hline
\end{tabular}

Panel B - Number of policy actions by micro type of intervention

\begin{tabular}{|c|c|c|c|c|c|c|c|c|c|c|c|c|}
\hline & \multicolumn{3}{|c|}{ Financial Sector Policies } & \multirow{2}{*}{$\begin{array}{c}\begin{array}{c}\text { Policy Inaction and } \\
\text { Bank Failures/Bailouts }\end{array} \\
\text { INABAIL_FAIL } \\
\end{array}$} & \multicolumn{2}{|c|}{$\begin{array}{c}\text { Expansionary } \\
\text { Monetary Policy }\end{array}$} & \multicolumn{3}{|c|}{$\begin{array}{c}\text { Restrictive Monetary } \\
\text { Policy } \\
\end{array}$} & \multirow{2}{*}{$\begin{array}{c}\begin{array}{c}\text { Fiscal Policy } \\
\& \text { State Aid }\end{array} \\
\text { FISPOL }\end{array}$} & \multirow{2}{*}{$\begin{array}{c}\begin{array}{c}\text { Other } \\
\text { Measures }\end{array} \\
\text { OTHER } \\
\end{array}$} & \multirow{2}{*}{$\begin{array}{c}\begin{array}{c}\text { End of recovery or } \\
\text { austerity measures }\end{array} \\
\text { END_AUS } \\
\end{array}$} \\
\hline & FA & FL & FR & & IRC & LIQ+ & CONTR & IRIU & ME & & & \\
\hline 2007 & 0 & 5 & 0 & 1 & 2 & 13 & 0 & 18 & 0 & 0 & 14 & 0 \\
\hline 2008 & 6 & 6 & 7 & 7 & 11 & 29 & 1 & 25 & 1 & 9 & 36 & 0 \\
\hline 2009 & 10 & 11 & 13 & 5 & 6 & 44 & 6 & 23 & 10 & 10 & 44 & 12 \\
\hline 2010 & 2 & 11 & 1 & 5 & 1 & 10 & 8 & 31 & 4 & 3 & 27 & 3 \\
\hline 2011 & 0 & 3 & 2 & 1 & 4 & 8 & 4 & 28 & 15 & 5 & 10 & 0 \\
\hline 2012 & 1 & 1 & 2 & 1 & 0 & 5 & 3 & 13 & 7 & 2 & 4 & 0 \\
\hline Total & 19 & 37 & 25 & 20 & 24 & 109 & 22 & 138 & 37 & 29 & 135 & 15 \\
\hline
\end{tabular}




\section{Table 2: Variable description}

This table describes all variables used in the empirical analysis run in the paper.

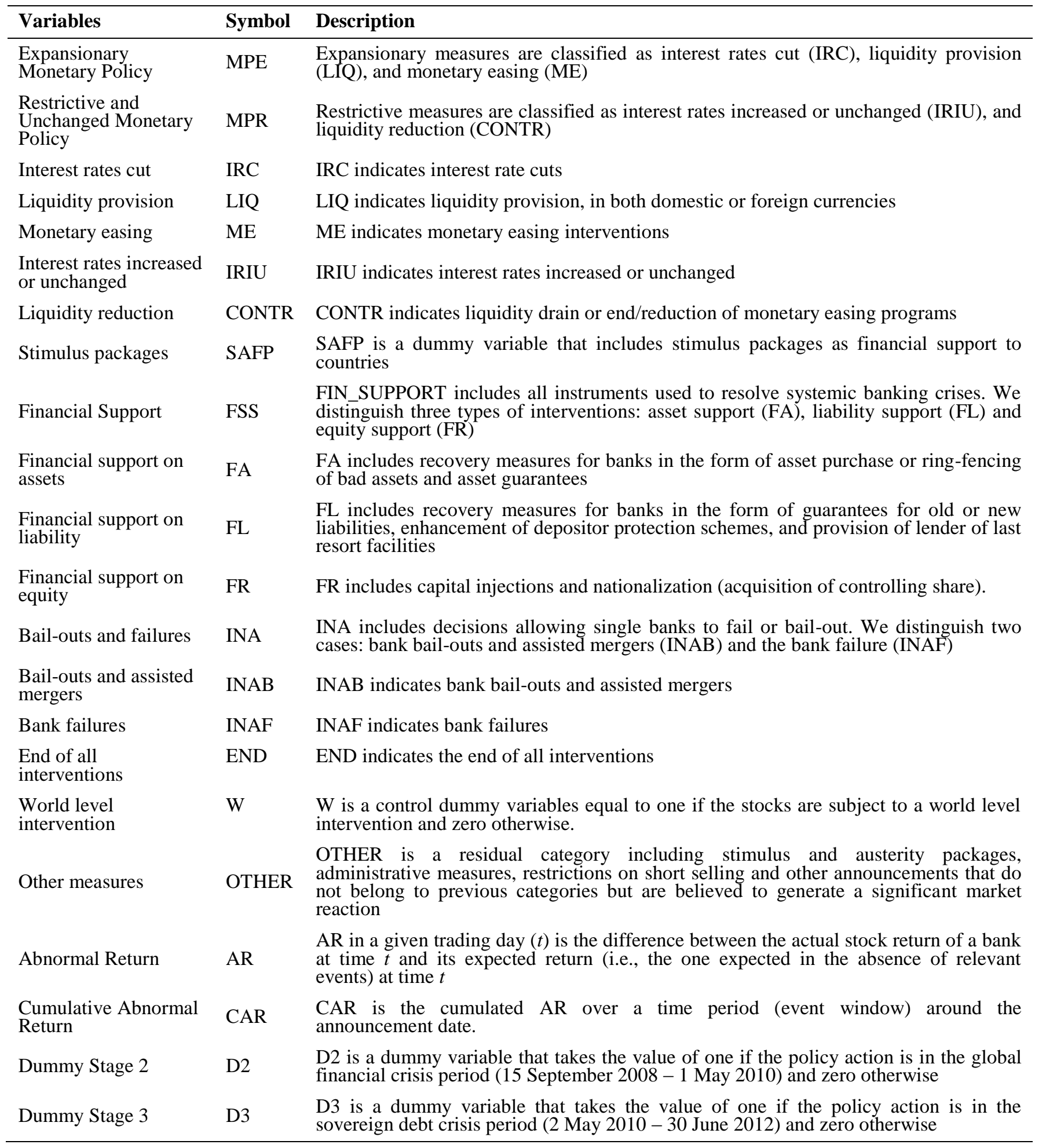




\section{Table 3: The market indices' reaction to policy intervention announcements: general model}

This table reports empirical results by running equation 1. The dependent variable is the Cumulative Abnormal Return (estimated focusing on the Stock Market Index proxied by FTSE broad indices) around policy announcements from between June 2007 and June 2012. In column (1), the dependent variable is the CAR calculated over the one-day $(0 ; 0)$ event window. In column $(2), y$ is the CAR over the 5 -day $(-1 ;+3)$ event window. In column $(3), y$ is the CAR over the 3 -day $(-1 ;+1)$ event window. In column $(4), y$ is the CAR calculated over the two-day $(0 ;+1)$ event window. In column $(5), y$ is the CAR calculated over the two-day $(-1 ; 0)$ event window. All variables are described in Table $2 . * * *, * *$, and $*$ denote that estimates are statistically significant at the $1 \%, 5 \%$ and $10 \%$ levels.

\begin{tabular}{|c|c|c|c|c|c|c|c|c|c|c|}
\hline & \multicolumn{2}{|l|}{ (1) } & \multicolumn{2}{|l|}{ (2) } & \multicolumn{2}{|l|}{ (3) } & \multicolumn{2}{|l|}{ (4) } & \multicolumn{2}{|l|}{ (5) } \\
\hline & Coeff. & Std. Err. & Coeff. & Std. Err. & Coeff. & Std. Err. & Coeff. & Std. Err. & Coeff. & Std. Err. \\
\hline MPE & $0.001 * * *$ & 0.0003 & 0.0008 & 0.0005 & -0.0006 & 0.0004 & 0.0004 & 0.0004 & 0.0000 & 0.0003 \\
\hline MPRU & 0.0000 & 0.0003 & -0.0003 & 0.0006 & $-0.0013 * * *$ & 0.0005 & $-0.0009 * *$ & 0.0004 & -0.0004 & 0.0004 \\
\hline FSS & $-0.0012 * * *$ & 0.0003 & -0.0001 & 0.0006 & $-0.0011^{* *}$ & 0.0005 & $-0.0015^{* * *} *$ & 0.0004 & $-0.0008 * *$ & 0.0004 \\
\hline INA & $-0.0023 * * *$ & 0.0005 & $0.002 *$ & 0.0010 & -0.0007 & 0.0008 & 0.0005 & 0.0007 & $-0.0035^{* * *} *$ & 0.0007 \\
\hline OTHER & $-0.0006^{* *}$ & 0.0003 & 0.0005 & 0.0006 & -0.0003 & 0.0005 & $-0.0007 *$ & 0.0004 & -0.0002 & 0.0004 \\
\hline SAFP & 0.0005 & 0.0004 & -0.0008 & 0.0007 & 0.0002 & 0.0006 & 0.0005 & 0.0005 & 0.0001 & 0.0005 \\
\hline END & 0.0007 & 0.0008 & $0.004 * * *$ & 0.0015 & 0.0001 & 0.0013 & 0.0009 & 0.0010 & -0.0001 & 0.0010 \\
\hline W & $-0.0006^{*}$ & 0.0004 & $-0.0029 * * *$ & 0.0007 & $-0.0011^{*}$ & 0.0006 & -0.0003 & 0.0005 & $-0.0014 * * *$ & 0.0005 \\
\hline D2 & $0.0008 * *$ & 0.0003 & $0.0019 * * *$ & 0.0007 & $0.0018 * * *$ & 0.0005 & $0.0016^{* * *}$ & 0.0004 & $0.001 * *$ & 0.0004 \\
\hline D3 & -0.0002 & 0.0003 & $0.0019 * * *$ & 0.0007 & $0.0014 * * *$ & 0.0006 & $0.0012 * * *$ & 0.0005 & 0.0001 & 0.0004 \\
\hline CONS & $0.0011^{*}$ & 0.0006 & -0.0010 & 0.0013 & -0.0003 & 0.0010 & -0.0002 & 0.0009 & 0.0010 & 0.0008 \\
\hline Year*Country Fixed Eff. & YES & & YES & & YES & & YES & & YES & \\
\hline Industry Fixed Effect & YES & & YES & & YES & & YES & & YES & \\
\hline Day of the week Fixed Effect & YES & & YES & & YES & & YES & & YES & \\
\hline Number of observations & 7169 & & 7169 & & 7169 & & 7169 & & 7169 & \\
\hline $\mathrm{R}$-squared & 0.0106 & & 0.0072 & & 0.004 & & 0.0061 & & 0.0073 & \\
\hline
\end{tabular}




\section{Table 4: The banking industry indices' reaction to policy intervention announcements: general model}

This table reports empirical results by running equation 1. The dependent variable is the Cumulative Abnormal Return (estimated focusing on the Stock Banking Industry Index proxied by FTSE Bank Index) around policy announcements from between June 2007 and June 2012 . In column (1), the dependent variable is the CAR calculated over the one-day $(0 ; 0)$ event window. In column $2, y$ is the CAR over the 5 -day $(-1 ;+3)$ event window. In column $(3), y$ is the CAR over the 3 -day $(-$ $1 ;+1)$ event window. In column $(4)$, y is the CAR calculated over the two-day $(0 ;+1)$ event window. In column (5), $y$ is the CAR calculated over the two-day $(-1 ; 0)$ event window. All variables are described in Table $2 . * * * * *$, and $*$ denote that estimates are statistically significant at the $1 \%, 5 \%$ and $10 \%$ levels.

\begin{tabular}{|c|c|c|c|c|c|c|c|c|c|c|}
\hline & \multicolumn{2}{|c|}{ (1) } & \multicolumn{2}{|c|}{ (2) } & \multicolumn{2}{|c|}{ (3) } & \multicolumn{2}{|c|}{ (4) } & \multicolumn{2}{|c|}{ (5) } \\
\hline & Coeff. & Std. Err. & Coeff. & Std. Err. & Coeff. & Std. Err. & Coeff. & Std. Err. & Coeff. & Std. Err. \\
\hline MPE & $0.0016^{* * *}$ & 0.0005 & $0.0051 * * *$ & 0.0016 & $0.0024 * *$ & 0.0012 & $0.0023^{* *}$ & 0.0009 & $0.0019 *$ & 0.001 \\
\hline MPRU & 0.0006 & 0.0006 & $0.0074 * * *$ & 0.0019 & $0.0035 * *$ & 0.0014 & $0.0022 * *$ & 0.0011 & 0.0016 & 0.0011 \\
\hline FSS & 0.0007 & 0.0006 & $0.0081 * * *$ & 0.0018 & $0.0057 * * *$ & 0.0014 & $0.0037 * * *$ & 0.0011 & $0.0026 * *$ & 0.0011 \\
\hline INA & -0.0014 & 0.001 & $0.0073 * *$ & 0.003 & 0.0001 & 0.0023 & -0.0014 & 0.0017 & 0.0002 & 0.0018 \\
\hline OTHER & 0.0008 & 0.0005 & 0.0019 & 0.0017 & 0.0002 & 0.0013 & 0.0014 & 0.001 & -0.0008 & 0.001 \\
\hline SAFP & 0.0005 & 0.0007 & -0.0014 & 0.0023 & -0.0012 & 0.0017 & -0.0004 & 0.0013 & -0.0006 & 0.0014 \\
\hline END & 0.0018 & 0.0015 & -0.0046 & 0.0047 & -0.0001 & 0.0035 & 0.0022 & 0.0027 & -0.0009 & 0.0028 \\
\hline W & -0.0003 & 0.0007 & $-0.0045^{* *}$ & 0.0022 & -0.0015 & 0.0016 & $-0.0025 * *$ & 0.0013 & 0.0000 & 0.0013 \\
\hline D2 & -0.0009 & 0.0006 & -0.0004 & 0.002 & -0.001 & 0.0015 & 0.0000 & 0.0012 & -0.0019 & 0.0012 \\
\hline D3 & -0.0004 & 0.0007 & 0.0014 & 0.0021 & -0.0003 & 0.0016 & 0.0004 & 0.0012 & -0.0011 & 0.0012 \\
\hline CONS & $-0.0022 *$ & 0.0012 & -0.0032 & 0.0039 & -0.0042 & 0.0029 & $-0.0042 *$ & 0.0022 & -0.001 & 0.0023 \\
\hline Year*Country Fixed Eff. & \multicolumn{2}{|c|}{ YES } & \multicolumn{2}{|c|}{ YES } & \multicolumn{2}{|c|}{ YES } & \multicolumn{2}{|c|}{ YES } & \multicolumn{2}{|c|}{ YES } \\
\hline Industry Fixed Effect & \multicolumn{2}{|c|}{ YES } & \multicolumn{2}{|c|}{ YES } & \multicolumn{2}{|c|}{ YES } & \multicolumn{2}{|c|}{ YES } & \multicolumn{2}{|c|}{ YES } \\
\hline Day of the week fixed Effect & \multicolumn{2}{|c|}{ YES } & \multicolumn{2}{|c|}{ YES } & \multicolumn{2}{|c|}{ YES } & \multicolumn{2}{|c|}{ YES } & \multicolumn{2}{|c|}{ YES } \\
\hline Number of observations & \multicolumn{2}{|c|}{7169} & \multicolumn{2}{|c|}{7169} & \multicolumn{2}{|c|}{7169} & \multicolumn{2}{|c|}{7169} & \multicolumn{2}{|c|}{7169} \\
\hline R-squared & \multicolumn{2}{|c|}{0.0053} & \multicolumn{2}{|c|}{0.0058} & \multicolumn{2}{|c|}{0.0066} & \multicolumn{2}{|c|}{0.0079} & \multicolumn{2}{|c|}{0.0040} \\
\hline
\end{tabular}




\section{Table 5: The non-banking industry indices reaction to policy intervention announcements: general model}

This table reports empirical results by running equation 1 . The dependent variable is the Cumulative Abnormal Return obtained for each country by the following FTSE local sectorial indices: FTSE INDUSTRIALS, FTSE TECHNOLOGY, FTSE TELECOM, FTSE UTILITIES, FTSE CON \& MAT, FTSE CONSUMER GDS, FTSE CONSUMER SVS, FTSE BASIC MATS, and FTSE HEALTH CAR around policy announcements from between June 2007 and June 2012. In column (1), the dependent variable is the CAR calculated over the one-day $(0 ; 0)$ event window. In column (2), $y$ is the CAR over the 5-day (-1; +3$)$ event window. In column $(3)$, $y$ is the CAR over the 3 -day $(-1 ;+1)$ event window. In column $(4), y$ is the CAR calculated over the two-day $(0 ;+1)$ event window. In column $(5), y$ is the CAR calculated over the two-day $(-1 ; 0)$ event window. All variables are described in Table $2 . * * *, * *$, and $*$ denote that estimates are statistically significant at the $1 \%$, $5 \%$ and $10 \%$ levels. Results for each single non-banking industry are reported in the Appendix, which can be obtained upon request from the authors or downloaded from the authors' website.

\begin{tabular}{|c|c|c|c|c|c|c|c|c|c|c|}
\hline & \multicolumn{2}{|c|}{ (1) } & \multicolumn{2}{|c|}{ (2) } & \multicolumn{2}{|c|}{ (3) } & \multicolumn{2}{|c|}{ (4) } & \multicolumn{2}{|c|}{ (5) } \\
\hline & Coeff. & Std. Err. & Coeff. & Std. Err. & Coeff. & Std. Err. & Coeff. & Std. Err. & Coeff. & Std. Err. \\
\hline MPE & $-0.0006 * * *$ & 0.0002 & -0.0004 & 0.0003 & $-0.0006 * *$ & 0.0002 & $-0.0005 * * *$ & 0.0001 & $-0.0005^{* *}$ & 0.0002 \\
\hline MPRU & $-0.0005^{* *}$ & 0.0002 & $-0.0009 * *$ & 0.0004 & $-0.0005 *$ & 0.0003 & $-0.0003 *$ & 0.0002 & -0.0003 & 0.0002 \\
\hline FSS & -0.0003 & 0.0002 & -0.0005 & 0.0003 & -0.0002 & 0.0003 & -0.0001 & 0.0002 & 0.0001 & 0.0002 \\
\hline INA & 0.0005 & 0.0004 & $-0.0011^{* *}$ & 0.0006 & 0.0002 & 0.0004 & $0.0006 * *$ & 0.0003 & 0.0003 & 0.0004 \\
\hline OTHER & $-0.0007 * * *$ & 0.0002 & -0.0005 & 0.0003 & $-0.0005^{*}$ & 0.0003 & $-0.0003^{*}$ & 0.0001 & 0.0000 & 0.0002 \\
\hline SAFP & -0.0003 & 0.0003 & $0.0007 *$ & 0.0004 & -0.0001 & 0.0003 & -0.0003 & 0.0002 & 0.0000 & 0.0003 \\
\hline END & -0.0002 & 0.0006 & 0.0004 & 0.0009 & 0.0009 & 0.0007 & -0.0003 & 0.0004 & 0.0008 & 0.0006 \\
\hline $\mathrm{W}$ & $0.0004 *$ & 0.0003 & 0.0004 & 0.0004 & 0.0002 & 0.0003 & 0.0001 & 0.0002 & -0.0002 & 0.0003 \\
\hline D2 & $0.001 * * *$ & 0.0002 & $0.0016 * * *$ & 0.0004 & $0.0013 * * *$ & 0.0003 & $0.0006^{* * * *}$ & 0.0002 & $0.0008 * * *$ & 0.0002 \\
\hline D3 & $0.0006^{* *}$ & 0.0003 & 0.0003 & 0.0004 & $0.0005^{*}$ & 0.0003 & $0.0005 * * *$ & 0.0002 & $0.0005^{*}$ & 0.0003 \\
\hline CONS & -0.0005 & 0.0005 & -0.0007 & 0.0008 & -0.0006 & 0.0006 & -0.0004 & 0.0004 & -0.0005 & 0.0005 \\
\hline Year*Country Fixed Eff. & \multicolumn{2}{|c|}{ YES } & \multicolumn{2}{|c|}{ YES } & \multicolumn{2}{|c|}{ YES } & \multicolumn{2}{|c|}{ YES } & \multicolumn{2}{|c|}{ YES } \\
\hline Industry Fixed Effect & \multicolumn{2}{|c|}{ YES } & \multicolumn{2}{|c|}{ YES } & \multicolumn{2}{|c|}{ YES } & \multicolumn{2}{|c|}{ YES } & \multicolumn{2}{|c|}{ YES } \\
\hline Day of the week Fixed Effect & \multicolumn{2}{|c|}{ YES } & \multicolumn{2}{|c|}{ YES } & \multicolumn{2}{|c|}{ YES } & \multicolumn{2}{|c|}{ YES } & \multicolumn{2}{|c|}{ YES } \\
\hline Number of observations & \multicolumn{2}{|c|}{56084} & \multicolumn{2}{|c|}{56084} & \multicolumn{2}{|c|}{56084} & \multicolumn{2}{|c|}{56084} & \multicolumn{2}{|c|}{56084} \\
\hline R-squared & \multicolumn{2}{|c|}{0.0010} & \multicolumn{2}{|c|}{0.0011} & \multicolumn{2}{|c|}{0.0008} & \multicolumn{2}{|c|}{0.0010} & \multicolumn{2}{|c|}{0.0009} \\
\hline
\end{tabular}




\section{Table 6: Stock market reactions to monetary policy announcements: impact model on expansionary measures}

This table reports empirical results by running equation 2, where we replace the macro category "expansionary monetary" with its three components: IRC is a dummy variable that indicates interest rate cuts, LIQ is a dummy variable that indicates liquidity provision, ME is a dummy variable that indicates monetary easing intervention. IRC*D2, LIQ*D2, ME*D2, IRC*D3, LIQ*D3 and ME*D3 are interaction dummies accounting simultaneously for Policy action and sub-period effects. The dependent variable is the Cumulated Abnormal Returns estimated at the announcement day [i.e., the window $(0,0)]$. CARs are calculated focusing on the Stock Market General Index (i.e., proxied by FTSE broad Index), bank sector index (proxied by FTSE Bank Index), and non-Banking Sector indices (proxied by FTSE sectorial indices). We run similar models by estimating CAR over the event windows $(-1,0),(0,1),(1-, 1)$, and $(-1,3)$ to check the consistency of our results: the results are available upon request from the authors. All variables are described in Table $2 . * * *, * *$, and $*$ denote that estimates are statistically significant at the $1 \%, 5 \%$ and $10 \%$ levels.

\begin{tabular}{|c|c|c|c|c|c|c|c|c|c|c|c|c|}
\hline & \multicolumn{4}{|c|}{ Stock Market } & \multicolumn{4}{|c|}{ Bank Sector } & \multicolumn{4}{|c|}{ Non - Banking Sector } \\
\hline & \multicolumn{2}{|c|}{ (1) } & \multicolumn{2}{|c|}{ (2) } & \multicolumn{2}{|c|}{ (3) } & \multicolumn{2}{|c|}{ (4) } & \multicolumn{2}{|c|}{ (5) } & \multicolumn{2}{|c|}{ (6) } \\
\hline & Coeff. & Std. Err. & Coeff. & Std. Err. & Coeff. & Std. Err. & Coeff. & Std. Err. & Coeff. & Std. Err. & Coeff. & Std. Err. \\
\hline IRC & $-0.0011 *$ & 0.0006 & -0.0003 & 0.0010 & 0.0009 & 0.0011 & $0.0059 * * *$ & 0.0019 & $-0.0016^{* * *}$ & 0.0004 & $-0.0014 *$ & 0.0007 \\
\hline LIQ & $0.0007 * *$ & 0.0003 & 0.0000 & 0.0004 & $0.002 * * *$ & 0.0006 & 0.0013 & 0.0009 & -0.0001 & 0.0002 & $-0.0006^{*}$ & 0.0003 \\
\hline ME & $0.0011 * *$ & 0.0004 & $0.0024 * * *$ & 0.0006 & 0.0005 & 0.0009 & 0.0006 & 0.0014 & -0.0005 & 0.0003 & -0.0005 & 0.0003 \\
\hline MPRU & -0.0001 & 0.0003 & 0.0001 & 0.0003 & 0.0004 & 0.0006 & 0.0003 & 0.0006 & $-0.0007 * *$ & 0.0002 & $-0.0004 *$ & 0.0002 \\
\hline FSS & $-0.0015 * * *$ & 0.0003 & $-0.0013 * * *$ & 0.0003 & 0.0008 & 0.0006 & 0.0009 & 0.0006 & -0.0002 & 0.0002 & -0.0001 & 0.0002 \\
\hline INA & $-0.0027 * * *$ & 0.0005 & $-0.0027 * * *$ & 0.0005 & -0.0011 & 0.0010 & -0.0011 & 0.0010 & 0.0005 & 0.0004 & 0.0006 & 0.0004 \\
\hline OTHER & $-0.0008 * *$ & 0.0003 & $-0.0007 * *$ & 0.0003 & 0.0008 & 0.0005 & $0.001 *$ & 0.0006 & $-0.0007 * * *$ & 0.0002 & $-0.0007 * * *$ & 0.0002 \\
\hline SAFP & 0.0004 & 0.0004 & 0.0005 & 0.0004 & 0.0006 & 0.0007 & 0.0007 & 0.0007 & -0.0002 & 0.0003 & -0.0001 & 0.0003 \\
\hline END & 0.0008 & 0.0008 & 0.0008 & 0.0008 & 0.0015 & 0.0015 & 0.0015 & 0.0015 & -0.0003 & 0.0006 & -0.0005 & 0.0006 \\
\hline W & $-0.0076^{*}$ & 0.0004 & $-0.0008 * *$ & 0.0004 & -0.0004 & 0.0007 & -0.0004 & 0.0007 & $0.0005^{*}$ & 0.0003 & 0.0004 & 0.0003 \\
\hline D2 & $0.0015^{* *}$ & 0.0003 & $0.0013^{* *}$ & 0.0004 & $-0.002 * *$ & 0.0006 & $-0.002 * *$ & 0.0006 & $0.0014 * * *$ & 0.0002 & $0.0008 * * *$ & 0.0003 \\
\hline D3 & -0.0003 & 0.0004 & -0.0007 & 0.0004 & -0.0002 & 0.0007 & 0.0001 & 0.0007 & $0.0006^{* *}$ & 0.0003 & 0.0004 & 0.0003 \\
\hline IRC*D2 & & & -0.0003 & 0.0013 & & & $-0.0065 * * *$ & 0.0024 & & & -0.0003 & 0.0009 \\
\hline LIQ*D2 & & & $-0.0052 *$ & 0.0029 & & & $0.0214 * * *$ & 0.0059 & & & $-0.0097 * * *$ & 0.0022 \\
\hline $\mathrm{ME} * \mathrm{D} 2$ & & & $-0.0032 * * *$ & 0.0009 & & & 0.0000 & 0.0000 & & & $-0.0014 * *$ & 0.0007 \\
\hline IRC*D3 & & & -0.0014 & 0.0016 & & & $-0.0118 * * *$ & 0.0032 & & & 0.0006 & 0.0012 \\
\hline LIQ*D3 & & & $0.0067 * *$ & 0.0029 & & & $-0.0202 * * *$ & 0.0058 & & & $0.0106 * * *$ & 0.0022 \\
\hline ME*D3 & & & 0.0000 & 0.0000 & & & -0.0001 & 0.0018 & & & 0.0000 & 0.0000 \\
\hline CONS & $0.0012 *$ & 0.0006 & $0.0013 *$ & 0.0007 & $-0.0024 *$ & 0.0012 & $-0.0024 *$ & 0.0013 & -0.0007 & 0.0005 & -0.0007 & 0.0005 \\
\hline Year*Country Fixed Eff. & & YES & & YES & & YES & & YES & & YES & & YES \\
\hline Industry Fixed Effect & & YES & & YES & & NO & & NO & & YES & & YES \\
\hline Day of the week Fixed Effect & & YES & & YES & & YES & & YES & & YES & & YES \\
\hline Number of observations & & 7169 & & 7169 & & 7169 & & 7169 & & 56084 & & 56084 \\
\hline R-squared & & 0.0108 & & 0.0188 & & 0.016 & & 0.0195 & & 0.023 & & 0.0029 \\
\hline
\end{tabular}




\section{Table 7: Stock market reactions to monetary policy announcements: impact model on Restriction and unchanged measures}

This table reports empirical results by running equation 2, where we disentangle the macro category of "Restriction and unchanged measures" in its two components: CONTR is a dummy variable that indicates liquidity drain or end/reduction of monetary easing programs; IRIU is a dummy variable that indicates that interest rates increased or unchanged. IRIU*D2, CONT*D2, IRIU*D3, and CONT*D3 are interaction dummies accounting simultaneously for Policy action and sub-period effects. The dependent variable is the Cumulated Abnormal Returns estimated at the announcement day [i.e., the window (0,0)]. CARs are calculated focusing on the Stock Market General Index (i.e., proxied by FTSE broad Index), bank sector index (proxied by FTSE Bank Index), and non-Banking Sector indices (proxied by FTSE sectorial indices). We run similar models by estimating CAR over the event windows $(-1,0),(0,1),(1-, 1)$, and $(-1,3)$ to check the consistency of our results: the results are available upon request from the authors. All variables are described in Table $2 . * * *, * *$, and $*$ denote that estimates are statistically significant at the $1 \%$, $5 \%$ and $10 \%$ levels.

\begin{tabular}{|c|c|c|c|c|c|c|c|c|c|c|c|c|}
\hline & \multicolumn{4}{|c|}{ Stock Market } & \multicolumn{4}{|c|}{ Bank Sector } & \multicolumn{4}{|c|}{ Non - Banking Sector } \\
\hline & \multicolumn{2}{|c|}{$(1)$} & \multicolumn{2}{|l|}{ (2) } & \multicolumn{2}{|c|}{ (3) } & \multicolumn{2}{|c|}{ (4) } & \multicolumn{2}{|c|}{$(5)$} & \multicolumn{2}{|c|}{ (6) } \\
\hline & Coeff. & Std. Err. & Coeff. & Std. Err. & Coeff. & Std. Err. & Coeff. & Std. Err. & Coeff. & Std. Err. & Coeff. & Std. Err. \\
\hline CONTR & 0.0005 & 0.0006 & $0.0018 * *$ & 0.0007 & -0.0001 & 0.0011 & 0.0011 & 0.0014 & 0.0000 & 0.0004 & 0.0007 & 0.0007 \\
\hline IRIU & -0.0030 & 0.0003 & $-0.002 * * *$ & 0.0006 & $0.002 * * *$ & 0.0006 & 0.0010 & 0.0011 & $-0.0005 * *$ & 0.0002 & -0.0002 & 0.0004 \\
\hline MPE & $0.001 * * *$ & 0.0003 & $0.0009 * * *$ & 0.0003 & $0.0016^{* * *}$ & 0.0005 & $0.0015 * * *$ & 0.0005 & $-0.0006 * * *$ & 0.0002 & $-0.0006 * * *$ & 0.0002 \\
\hline FSS & $-0.0013 * * *$ & 0.0003 & $-0.0013 * * *$ & 0.0003 & 0.0007 & 0.0006 & 0.0007 & 0.0006 & -0.0003 & 0.0002 & -0.0004 & 0.0002 \\
\hline INA & $-0.0026 * * *$ & 0.0005 & $-0.0025 * * *$ & 0.0005 & -0.0013 & 0.0010 & -0.0012 & 0.0010 & 0.0005 & 0.0004 & 0.0005 & 0.0004 \\
\hline OTHER & $-0.0007 * *$ & 0.0003 & $-0.0007 * *$ & 0.0003 & 0.0007 & 0.0005 & 0.0007 & 0.0006 & $-0.0007 * * *$ & 0.0002 & $-0.0007 * * *$ & 0.0002 \\
\hline SAFP & 0.0003 & 0.0004 & 0.0003 & 0.0004 & 0.0009 & 0.0007 & 0.0009 & 0.0007 & -0.0003 & 0.0003 & -0.0003 & 0.0003 \\
\hline END & 0.0007 & 0.0008 & 0.0008 & 0.0008 & 0.0015 & 0.0015 & 0.0015 & 0.0015 & -0.0001 & 0.0006 & -0.0002 & 0.0006 \\
\hline W & $-0.0007 *$ & 0.0004 & $-0.0008 * *$ & 0.0004 & -0.0005 & 0.0007 & -0.0005 & 0.0007 & 0.0004 & 0.0003 & 0.0003 & 0.0003 \\
\hline D2 & $0.0015^{* * *}$ & 0.0003 & 0.0008 & 0.0004 & $-0.002 * *$ & 0.0006 & $-0.0018 * *$ & 0.0008 & $0.001 * * *$ & 0.0002 & $0.0017 * * *$ & 0.0003 \\
\hline D3 & 0.0008 & 0.0003 & -0.0001 & 0.0004 & -0.0011 & 0.0011 & -0.0011 & 0.0013 & $0.0011 * *$ & 0.0003 & $0.0008^{*}$ & 0.0003 \\
\hline CONTR*D2 & & & $-0.0032 * * *$ & 0.0012 & & & 0.0010 & 0.0014 & & & 0.0000 & 0.0000 \\
\hline IRIU*D2 & & & $0.0024 * * *$ & 0.0007 & & & 0.0018 & 0.0014 & & & $-0.0012 * *$ & 0.0005 \\
\hline CONTR*D3 & & & 0.0000 & 0.0000 & & & -0.0330 & 0.0022 & & & -0.0007 & 0.0009 \\
\hline IRIU*D3 & & & $0.0021 * * *$ & 0.0007 & & & 0.0008 & 0.0013 & & & 0.0005 & 0.0005 \\
\hline CONS & $0.0011 *$ & 0.0006 & $0.0017 * *$ & 0.0007 & $-0.0022 *$ & 0.0012 & -0.0021 & 0.0013 & -0.0005 & 0.0005 & -0.0006 & 0.0005 \\
\hline Year*Country Fixed Eff. & \multicolumn{2}{|l|}{ YES } & \multicolumn{2}{|l|}{ YES } & \multicolumn{2}{|c|}{ YES } & \multicolumn{2}{|c|}{ YES } & \multicolumn{2}{|c|}{ YES } & \multicolumn{2}{|c|}{ YES } \\
\hline Industry Fixed Effect & \multicolumn{2}{|l|}{ YES } & \multicolumn{2}{|l|}{ YES } & \multicolumn{2}{|c|}{ NO } & \multicolumn{2}{|c|}{ NO } & \multicolumn{2}{|c|}{ YES } & \multicolumn{2}{|c|}{ YES } \\
\hline Day of the week Fixed Effect & \multicolumn{2}{|l|}{ YES } & \multicolumn{2}{|l|}{ YES } & \multicolumn{2}{|c|}{ YES } & \multicolumn{2}{|c|}{ YES } & \multicolumn{2}{|c|}{ YES } & \multicolumn{2}{|c|}{ YES } \\
\hline Number of observations & \multicolumn{2}{|l|}{7169} & \multicolumn{2}{|l|}{7169} & \multicolumn{2}{|c|}{7169} & \multicolumn{2}{|c|}{7169} & 5608 & & 560 & \\
\hline R-squared & 0.005 & & 0.0177 & & 0.01 & & 0.0 & & 0.00 & & 0.00 & \\
\hline
\end{tabular}




\section{Table 8: Stock market reactions to fiscal policy announcements: impact model on State Aid \& Fiscal Policy Impact Model}

This table reports empirical results by running equation 2. SAFP*D2 and SAFP*D3 are interaction dummies accounting simultaneously for Policy action and subperiod effects. The dependent variable is the Cumulated Abnormal Returns estimated at the announcement day [i.e., the window (0)]. CARs are calculated focusing on the Stock Market General Index (i.e., proxied by FTSE broad Index), bank sector index (proxied by FTSE Bank Index), and non-Banking Sector indices (proxied by FTSE sectorial indices). We run similar models by estimating CAR over the event windows $(-1,0),(0,1),(1-, 1)$, and $(-1,3)$ to check the consistency of our results: the results are available upon request from the authors. All variables are described in Table $2 . * * *, * *$, and $*$ denote that estimates are statistically significant at the $1 \%, 5 \%$ and $10 \%$ levels.

\begin{tabular}{|c|c|c|c|c|c|c|c|c|c|c|c|c|}
\hline & \multicolumn{4}{|c|}{ Stock Market } & \multicolumn{4}{|c|}{ Bank Sector } & \multicolumn{4}{|c|}{ Non - Banking Sector } \\
\hline & \multicolumn{2}{|l|}{$(1)$} & \multicolumn{2}{|c|}{$(2)$} & \multicolumn{2}{|c|}{$(3)$} & \multicolumn{2}{|c|}{$(4)$} & \multicolumn{2}{|c|}{ (5) } & \multicolumn{2}{|l|}{$(6)$} \\
\hline & Coeff. & Std. Err. & Coeff. & Std. Err. & Coeff. & Std. Err. & Coeff. & Std. Err. & Coeff. & Std. Err. & Coeff. & Std. Err. \\
\hline SAFP & 0.0004 & 0.0004 & $0.0022 *$ & 0.0014 & 0.0006 & 0.0007 & 0.0009 & 0.0026 & -0.0003 & 0.0003 & $0.0026 * *$ & 0.0010 \\
\hline MPRU & 0.0006 & 0.0003 & 0.0001 & 0.0003 & 0.0006 & 0.0006 & 0.0006 & 0.0006 & $-0.0005 * *$ & 0.0002 & $-0.0005^{* *}$ & 0.0002 \\
\hline MPE & $0.0009 * * *$ & 0.0003 & $0.001 * * *$ & 0.0003 & $0.0018 * * *$ & 0.0005 & $0.0018 * * *$ & 0.0005 & $-0.0006 * * *$ & 0.0002 & $-0.0006^{* * *}$ & 0.0002 \\
\hline FSS & $-0.0014 * * *$ & 0.0003 & $-0.0013 * * *$ & 0.0003 & 0.0009 & 0.0006 & 0.0009 & 0.0006 & -0.0003 & 0.0002 & -0.0003 & 0.0002 \\
\hline INA & $-0.0026 * * *$ & 0.0005 & $-0.0026 * * *$ & 0.0005 & -0.0011 & 0.0001 & -0.0015 & 0.0010 & 0.0005 & 0.0004 & 0.0005 & 0.0004 \\
\hline OTHER & $-0.0007 * *$ & 0.0003 & $-0.0007 * *$ & 0.0003 & 0.0009 & 0.0006 & 0.0008 & 0.0005 & $-0.0007 * * *$ & 0.0002 & $-0.0007 * * *$ & 0.0002 \\
\hline END & 0.0009 & 0.0008 & 0.0009 & 0.0008 & 0.0015 & 0.0015 & 0.0011 & 0.0015 & -0.0002 & 0.0006 & -0.0001 & 0.0006 \\
\hline W & $-0.0007 * *$ & 0.0003 & $-0.0007 *$ & 0.0004 & -0.0005 & 0.0007 & -0.0004 & 0.0007 & $0.0004 *$ & 0.0003 & 0.0004 & 0.0003 \\
\hline D2 & $0.0015^{* *}$ & 0.0003 & $0.0016^{* *}$ & 0.0003 & $-0.002 * *$ & 0.0006 & $-0.002 * *$ & 0.0006 & $0.001 * * *$ & 0.0002 & $0.0016^{* * *}$ & 0.0003 \\
\hline D3 & 0.0009 & 0.0059 & $0.001 *$ & 0.0004 & -0.0001 & 0.0007 & -0.0001 & 0.0007 & $0.0011 * *$ & 0.0003 & $0.0015^{* * *}$ & 0.0003 \\
\hline SAFP*D2 & & & -0.0019 & 0.0014 & & & -0.0017 & 0.0027 & & & $-0.0027 * *$ & 0.0010 \\
\hline SAFP*D3 & & & -0.0022 & 0.0015 & & & 0.0016 & 0.0028 & & & $-0.0036^{* * *}$ & 0.0011 \\
\hline CONS & $0.0010^{* *}$ & 0.0005 & 0.0010 & 0.0006 & $-0.0021 * *$ & 0.0009 & $-0.0024 *$ & 0.0012 & -0.0005 & 0.0005 & -0.0006 & 0.0005 \\
\hline Year*Country Fixed Eff. & \multicolumn{2}{|l|}{ YES } & \multicolumn{2}{|c|}{ YES } & \multicolumn{2}{|c|}{ YES } & \multicolumn{2}{|c|}{ YES } & \multicolumn{2}{|c|}{ YES } & \multicolumn{2}{|c|}{ YES } \\
\hline Industry Fixed Effect & \multicolumn{2}{|l|}{ YES } & \multicolumn{2}{|c|}{ YES } & \multicolumn{2}{|c|}{ NO } & \multicolumn{2}{|c|}{ NO } & \multicolumn{2}{|c|}{ YES } & \multicolumn{2}{|c|}{ YES } \\
\hline Day of the week Fixed Effect & \multicolumn{2}{|l|}{ YES } & \multicolumn{2}{|c|}{ YES } & \multicolumn{2}{|c|}{ YES } & \multicolumn{2}{|c|}{ YES } & \multicolumn{2}{|c|}{ YES } & \multicolumn{2}{|c|}{ YES } \\
\hline Number of observations & \multicolumn{2}{|c|}{7169} & \multicolumn{2}{|c|}{7169} & \multicolumn{2}{|c|}{7169} & \multicolumn{2}{|c|}{7169} & \multicolumn{2}{|c|}{56084} & 5608 & \\
\hline R-squared & 0.015 & & 0.01 & & 0.01 & & 0.0 & & 0.02 & & 0.00 & \\
\hline
\end{tabular}




\section{Table 9: Stock market reactions to financial sector support policy announcements: Bank Failures and Bailouts Impact Model}

This table reports empirical results by running equation 2, where we replace the macro category INA with its two components: INAB is a dummy variable that indicates bank bailouts and assisted mergers; INAF is a dummy variable that indicates bank failures. INAB*D2, INAB*D3, INAF*D2, and INAF*D3 are interaction dummies accounting simultaneously for Policy action and sub-period effects. The dependent variable is the Cumulated Abnormal Returns estimated at the announcement day [i.e., the window (0,0)]. CARs are calculated focusing on the Stock Market General Index (i.e., proxied by FTSE broad Index), bank sector index (proxied by FTSE Bank Index), and non-Banking Sector indices (proxied by FTSE sectorial indices). We run similar models by estimating CAR over the event windows $(-1,0),(0,1),(1-, 1)$, and $(-1,3)$ to check the consistency of our results: the results are available upon request from the authors. All variables are described in Table $2 . * * * * *$, and $*$ denote that estimates are statistically significant at the $1 \%, 5 \%$ and $10 \%$ levels.

\begin{tabular}{|c|c|c|c|c|c|c|c|c|c|c|c|c|}
\hline & \multicolumn{4}{|c|}{ Stock Market } & \multicolumn{4}{|c|}{ Bank Sector } & \multicolumn{4}{|c|}{ Non - Banking Sector } \\
\hline & \multicolumn{2}{|c|}{$(1)$} & \multicolumn{2}{|c|}{ (2) } & \multicolumn{2}{|c|}{ (3) } & \multicolumn{2}{|c|}{ (4) } & \multicolumn{2}{|c|}{ (5) } & \multicolumn{2}{|c|}{ (6) } \\
\hline & Coeff. & Std. Err. & Coeff. & Std. Err. & Coeff. & Std. Err. & Coeff. & Std. Err. & Coeff. & Std. Err. & Coeff. & Std. Err. \\
\hline INAB & $-0.0025^{* * *}$ & 0.0005 & -0.0006 & 0.0010 & -0.0015 & 0.0019 & $0.0019 * * *$ & 0.0006 & 0.0005 & 0.0004 & $-0.0024 * * *$ & 0.0007 \\
\hline INAF & 0.0008 & 0.0015 & $-0.0045^{* *}$ & 0.0021 & 0.0002 & 0.0041 & $-0.0025 * * *$ & 0.0005 & -0.0014 & 0.0011 & $-0.0036^{* *}$ & 0.0015 \\
\hline MPE & 0.0001 & 0.0003 & 0.0001 & 0.0003 & $0.0016^{* *}$ & 0.0006 & $0.0006 * * *$ & 0.0002 & $-0.0005^{* *}$ & 0.0002 & $-0.0006^{* *}$ & 0.0002 \\
\hline MPRU & $0.001 * * *$ & 0.0003 & $0.0011^{* * *}$ & 0.0003 & $0.0018 * * *$ & 0.0005 & 0.0005 & 0.0018 & $-0.0006 * * *$ & 0.0002 & $-0.0007 * * *$ & 0.0002 \\
\hline FSS & $-0.0012 * * *$ & 0.0003 & $-0.0013 * * *$ & 0.0003 & 0.0008 & 0.0006 & 0.0008 & 0.0041 & -0.0003 & 0.0002 & $-0.0004 *$ & 0.0002 \\
\hline OTHER & $-0.0006^{*}$ & 0.0003 & $-0.0006^{*}$ & 0.0003 & 0.0009 & 0.0006 & 0.0008 & 0.0006 & $-0.0008 * * *$ & 0.0002 & $-0.0008 * * *$ & 0.0002 \\
\hline SAFP & 0.0003 & 0.0004 & 0.0005 & 0.0004 & 0.0004 & 0.0007 & 0.0007 & 0.0007 & -0.0003 & 0.0003 & -0.0003 & 0.0003 \\
\hline END & 0.0008 & 0.0008 & 0.0008 & 0.0008 & 0.0016 & 0.0015 & 0.0016 & 0.0015 & -0.0003 & 0.0006 & -0.0001 & 0.0006 \\
\hline $\mathrm{W}$ & $-0.0007^{*}$ & 0.0004 & $-0.0007 *$ & 0.0004 & -0.0006 & 0.0007 & -0.0006 & 0.0007 & $0.0002 *$ & 0.0003 & $0.0005^{*}$ & 0.0003 \\
\hline D2 & $0.0015 * * *$ & 0.0003 & $0.0018 * * *$ & 0.0003 & $-0.002 * *$ & 0.0007 & -0.0011 & 0.0007 & $0.001 * * *$ & 0.0002 & $0.0009 * *$ & 0.0003 \\
\hline D3 & 0.0009 & 0.0003 & $-0.0011^{*}$ & 0.0004 & -0.0007 & 0.0007 & -0.0009 & 0.0007 & $0.0005 * *$ & 0.0003 & 0.0007 & 0.0003 \\
\hline INAB $* \mathrm{D} 2$ & & & $-0.0035^{* *}$ & 0.0012 & & & $-0.0083 * * *$ & 0.0023 & & & $0.0047 * * *$ & 0.0009 \\
\hline INAF*D2 & & & $0.0116^{* * *}$ & 0.0029 & & & 0.0080 & 0.0057 & & & 0.0032 & 0.0021 \\
\hline INAB*D3 & & & -0.0013 & 0.0017 & & & 0.0000 & 0.0031 & & & 0.0012 & 0.0012 \\
\hline INAF*D3 & & & 0.0000 & 0.0000 & & & 0.0000 & 0.0000 & & & & \\
\hline CONS & 0.0010 & 0.0006 & 0.0008 & 0.0006 & 0.0002 & 0.0012 & $-0.0029 * *$ & 0.0012 & -0.0004 & 0.0005 & 0.0000 & 0.0005 \\
\hline Year*Country Fixed Eff. & \multicolumn{2}{|c|}{ YES } & \multicolumn{2}{|c|}{ YES } & \multicolumn{2}{|c|}{ YES } & \multicolumn{2}{|c|}{ YES } & \multicolumn{2}{|c|}{ YES } & \multicolumn{2}{|c|}{ YES } \\
\hline Industry Fixed Effect & \multicolumn{2}{|c|}{ YES } & \multicolumn{2}{|c|}{ YES } & \multicolumn{2}{|c|}{ NO } & \multicolumn{2}{|c|}{ NO } & \multicolumn{2}{|c|}{ YES } & \multicolumn{2}{|c|}{ YES } \\
\hline Day of the week Fixed Effect & \multicolumn{2}{|c|}{ YES } & \multicolumn{2}{|c|}{ YES } & \multicolumn{2}{|c|}{ YES } & \multicolumn{2}{|c|}{ YES } & \multicolumn{2}{|c|}{ YES } & \multicolumn{2}{|c|}{ YES } \\
\hline Number of observations & \multicolumn{2}{|c|}{7169} & \multicolumn{2}{|c|}{7169} & \multicolumn{2}{|c|}{7169} & \multicolumn{2}{|c|}{7169} & 5608 & & 5608 & \\
\hline R-squared & 0.00 & & 0.01 & & 0.01 & & 0.01 & & 0.00 & & 0.00 & \\
\hline
\end{tabular}




\section{Table 10: Stock market reactions to Financial Sector Policies announcements: impact model}

This table reports empirical results by running equation 2, where we replace the macro category Financial Sector Policy with its three components: FL is a dummy variable that includes recovery measures for banks in the form of guarantees for old or new liabilities, enhancement of depositor protection schemes, and provision of lender of last resort facilities; FR is a dummy variable that includes capital injections and nationalization (acquisition of controlling share); FA includes recovery measures for banks in the form of asset purchase or ring-fencing of bad assets and asset guarantees. FL*D2, FL*D3, FR*D2, FR*D3, FA*D2, and FA*D3 are interaction dummies accounting simultaneously for Policy action and sub-period effects. The dependent variable is the Cumulated Abnormal Returns estimated at the announcement day [i.e., the window $(0,0)]$. CARs are calculated focusing on the Stock Market General Index (i.e., proxied by FTSE broad Index), bank sector index (proxied by FTSE Bank Index), and non-Banking Sector indices (proxied by FTSE sectorial indices). We run similar models by estimating CAR over the event windows $(-1,0),(0,1),(1-, 1)$, and $(-1,3)$ to check the consistency of our results: the results are available upon request from the authors. All variables are described in Table $2 . * * * * *$, and $*$ denote that estimates are statistically significant at the $1 \%, 5 \%$ and $10 \%$ levels.

\begin{tabular}{|c|c|c|c|c|c|c|c|c|c|c|c|c|}
\hline & \multicolumn{4}{|c|}{ Stock Market } & \multicolumn{4}{|c|}{ Bank Sector } & \multicolumn{4}{|c|}{ Non - Banking Sector } \\
\hline & \multicolumn{2}{|l|}{$(1)$} & \multicolumn{2}{|c|}{$(2)$} & \multicolumn{2}{|c|}{ (3) } & \multicolumn{2}{|c|}{ (4) } & \multicolumn{2}{|c|}{$(5)$} & \multicolumn{2}{|c|}{ (6) } \\
\hline & Coeff. & Std. Err. & Coeff. & Std. Err. & Coeff. & Std. Err. & Coeff. & Std. Err. & Coeff. & Std. Err. & Coeff. & Std. Err. \\
\hline FA & $0.0011 * * *$ & 0.0005 & $0.0065 * * *$ & 0.0017 & 0.0000 & 0.0009 & $-0.0072 * *$ & 0.0034 & $0.0013 * * *$ & 0.0003 & -0.0002 & 0.0013 \\
\hline FL & -0.0004 & 0.0003 & $-0.002 * *$ & 0.0010 & 0.0000 & 0.0007 & -0.0018 & 0.0019 & $-0.0007 * * *$ & 0.0003 & -0.0002 & 0.0007 \\
\hline FR & $-0.0014 * * *$ & 0.0004 & -0.0022 & 0.0021 & -0.0002 & 0.0008 & -0.0030 & 0.0041 & -0.0001 & 0.0003 & $-0.0035^{* *}$ & 0.0016 \\
\hline MPE & $0.0011 * * *$ & 0.0003 & $0.0012 * * *$ & 0.0003 & $0.0015 * * *$ & 0.0005 & $0.0015 * * *$ & 0.0005 & $-0.0005 * * *$ & 0.0002 & $-0.0006 * * *$ & 0.0002 \\
\hline MPRU & 0.0003 & 0.0003 & 0.0006 & 0.0003 & $0.0014 * * *$ & 0.0006 & $0.0016^{* *}$ & 0.0006 & $-0.0005 * *$ & 0.0002 & $-0.0006 * * *$ & 0.0002 \\
\hline INA & $-0.0025 * * *$ & 0.0005 & $-0.0025 * * *$ & 0.0005 & -0.0014 & 0.0010 & -0.0012 & 0.0010 & 0.0005 & 0.0004 & 0.0005 & 0.0004 \\
\hline OTHER & -0.0005 & 0.0003 & -0.0004 & 0.0003 & 0.0006 & 0.0005 & 0.0005 & 0.0006 & $-0.0008 * * *$ & 0.0002 & $-0.0008 * * *$ & 0.0002 \\
\hline SAFP & 0.0004 & 0.0004 & $0.0005 *$ & 0.0004 & 0.0008 & 0.0007 & 0.0008 & 0.0007 & -0.0003 & 0.0003 & -0.0004 & 0.0003 \\
\hline END & 0.0010 & 0.0008 & 0.0010 & 0.0008 & 0.0014 & 0.0015 & 0.0004 & 0.0015 & -0.0001 & 0.0006 & -0.0001 & 0.0006 \\
\hline W & $-0.0008 * *$ & 0.0004 & $-0.0008 * *$ & 0.0004 & -0.0003 & 0.0007 & -0.0005 & 0.0007 & 0.0004 & 0.0003 & 0.0003 & 0.0003 \\
\hline D2 & $0.0012 * *$ & 0.0003 & $0.0012 * *$ & 0.0004 & -0.0006 & 0.0006 & -0.0008 & 0.0007 & $0.0013 * * *$ & 0.0002 & $0.0007 * * *$ & 0.0003 \\
\hline D3 & -0.0002 & 0.0003 & -0.0007 & 0.0004 & -0.0004 & 0.0007 & -0.0008 & 0.0007 & $0.0016 * *$ & 0.0003 & $0.0007 * * *$ & 0.0003 \\
\hline $\mathrm{FA} * \mathrm{D} 2$ & & & $-0.0061 * * *$ & 0.0018 & & & $0.008 * *$ & 0.0035 & & & 0.0017 & 0.0013 \\
\hline FL*D2 & & & $0.002 *$ & 0.0011 & & & 0.0007 & 0.0021 & & & -0.0001 & 0.0008 \\
\hline $\mathrm{FR} * \mathrm{D} 2$ & & & 0.0022 & 0.0222 & & & 0.0034 & 0.0041 & & & $0.0034 * *$ & 0.0016 \\
\hline FA*D3 & & & $-0.0049 *$ & 0.0027 & & & 0.0074 & 0.0053 & & & 0.0003 & 0.0020 \\
\hline FL*D3 & & & 0.0019 & 0.0012 & & & 0.0037 & 0.0024 & & & $-0.0023 * * *$ & 0.0009 \\
\hline FR*D3 & & & -0.0002 & 0.0024 & & & -0.0005 & 0.0047 & & & $0.0025^{*}$ & 0.0018 \\
\hline CONS & 0.0009 & 0.0006 & 0.0009 & 0.0006 & $-0.002 *$ & 0.0012 & -0.0017 & 0.0013 & -0.0005 & 0.0005 & -0.0003 & 0.0005 \\
\hline Year*Country Fixed Eff. & \multicolumn{2}{|c|}{ YES } & \multicolumn{2}{|c|}{ YES } & \multicolumn{2}{|c|}{ YES } & \multicolumn{2}{|c|}{ YES } & \multicolumn{2}{|c|}{ YES } & \multicolumn{2}{|c|}{ YES } \\
\hline Industry Fixed Effect & \multicolumn{2}{|c|}{ YES } & \multicolumn{2}{|c|}{ YES } & \multicolumn{2}{|c|}{ NO } & \multicolumn{2}{|c|}{ NO } & \multicolumn{2}{|c|}{ YES } & \multicolumn{2}{|c|}{ YES } \\
\hline Day of the week Fixed Effect & \multicolumn{2}{|c|}{ YES } & \multicolumn{2}{|c|}{ YES } & \multicolumn{2}{|c|}{ YES } & \multicolumn{2}{|c|}{ YES } & \multicolumn{2}{|c|}{ YES } & \multicolumn{2}{|c|}{ YES } \\
\hline Number of observations & \multicolumn{2}{|c|}{7169} & \multicolumn{2}{|c|}{7169} & 716 & & 71 & & 560 & & 5608 & \\
\hline R-squared & 0.015 & & 0.01 & & 0.010 & & 0.0 & & 0.00 & & 0.00 & \\
\hline
\end{tabular}




\section{Table 11: Stock market reactions to Anticipated and Surprise effects}

This table reports empirical results where we focus on monetary policy actions based on interest rate decisions, and we disentangle the "expected" and "unexpected" effects following the approach proposed by Bernanke and Kuttner (2005). The dependent variable is the Cumulated Abnormal Returns estimated at the announcement day [i.e., the window $(0,0)]$. CARs are calculated focusing on the Stock Market General Index (i.e., proxied by FTSE broad Index), bank sector index (proxied by FTSE Bank Index), and non-Banking Sector indices (proxied by FTSE sectorial indices). We run similar models by estimating CAR over the event windows $(-1,0),(0,1),(1-, 1)$, and $(-1,3)$ to check the consistency of our results: the results are available upon request from the authors. All variables are described in Table 2. ***, **, and * denote that estimates are statistically significant at the $1 \%, 5 \%$ and $10 \%$ levels.

\begin{tabular}{|c|c|c|c|c|c|c|}
\hline & \multirow{2}{*}{\multicolumn{2}{|c|}{$\frac{\text { General Index Model }}{(1)}$}} & \multirow{2}{*}{\multicolumn{2}{|c|}{$\frac{\text { Bank sector Model }}{(2)}$}} & \multirow{2}{*}{\multicolumn{2}{|c|}{$\frac{\text { Non- Banking Sector Mode }}{(3)}$}} \\
\hline & & & & & & \\
\hline & Coeff & St. Err & Coeff & St. Err & Coeff & St. Err \\
\hline Expected & $-0.0035^{* * *}$ & 0.0012 & 0.0032 & 0.0032 & $-0.0013^{*}$ & 0.0007 \\
\hline Unexpected & $-0.0041 * * *$ & 0.0013 & 0.0034 & 0.0035 & $-0.0014^{*}$ & 0.0007 \\
\hline Cons & -0.0006 & 0.0002 & -0.0006 & 0.0004 & -0.0001 & 0.0001 \\
\hline Year*Country Fixed Eff. & $\mathrm{YE}$ & & & & & \\
\hline Day of the week Fixed Effect & $\mathrm{YH}$ & & & & & \\
\hline Industry Fixed Effect & $\mathrm{YE}$ & & & & & \\
\hline Number of observations & 50 & & & & & \\
\hline R-squared & 0.01 & & & & & \\
\hline
\end{tabular}

